\title{
The Prospect of Human Cloning: Improving Nature or Dooming the Species?
}

\author{
Judith F. Daar
}

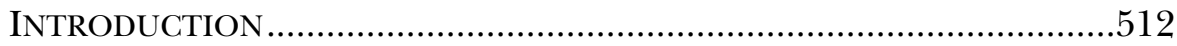

I. GAGING THE RESPONSE TO HUMAN CLONING .............................517

A. Initial Reactions and Actions ................................................517

B. Recent Attitudes Toward Human Cloning ..................................519

II. CAN A BAN ON Human RePRoductive Cloning BE Justified? ...524

A. Is a Ban on Human Cloning Moral?..............................................525

1. Banning Human Cloning: A View From Utilitarianism ...526

a. $\quad$ Possible Benefits of Reproductive Cloning …..............527

b. $\quad$ Possible Harms of Reproductive Cloning ....................530

c. Criticism of Utilitarianism as a Moral Theory .............535

2. Banning Human Cloning: A View From Deontology ........537

B. Is a Ban on Human Cloning Legal?..........................................541

1. Does a Cloning Ban Violate Protected Procreational

Liberty? ......................................................................543

2. Is a Total Ban on Human Cloning Unconstitutionally

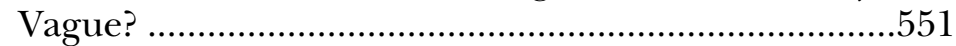

C. Is a Ban on Human Cloning Practical?........................................558

1. Successes and Failures in Animal Cloning .......................559

2. Inroads in Human Cloning..............................................564

3. The Effects of Banning Conduct ..................................568

III. CONCLUSION ..........................................................................572

\footnotetext{
* Professor of Law, Whittier Law School. An earlier version of this article was presented as the 2002 Johnson \& Johnson Healthcare Lecture at the University of South Carolina on April 16, 2002. I am indebted to Mariann Nystrom, Whittier Law School class of 2003, for her stellar research assistance. As always, I am grateful for Eric Daar's careful editing of and abiding interest in my work. This article is dedicated to the memory of Sylvia Freedel, whose views on cloning and myriad other topics have provided a lifetime of inspiration.
} 


\section{INTRODUCTION}

On February 23, 1997, it seemed that the world paused, if only for a moment, to reflect upon the future of the human species. The announcement by Scottish scientists, Ian Wilmut and Keith Campbell, that they had orchestrated the birth of Dolly the sheep, the world's first cloned mammal, ignited a worldwide debate about the glory and tragedy of science. $\quad$ For many, Dolly was a shocking symbol of biotechnology raging out of control, warranting a swift and decisive halting of any further experimentation in the cloning arena before its inevitable spillover to the human race. For a smaller group, Dolly was a marvelous and long-awaited sign that a century-old inquiry into the possibility of asexual reproduction had yielded a tentative answer. For both groups, and for the myriad whose views fall somewhere in between, the past six years have supplied sufficient fuel to ensure that the cloning fires will burn long into the future.

In the six years since the announcement of Dolly's birth, we have undertaken to grasp some of the scientific methods associated with cloning. Importantly, many now understand that cloning is not a single technique, but rather refers to ways in which the genome of an organism can be replicated. ${ }^{2}$ According to the American Society for Reproductive Medicine, the following three techniques are currently referred to as cloning: 1) reproductive cloning; 2) therapeutic cloning; and 3) embryonic cloning. ${ }^{3}$ Each of these techniques involves numerous scientific steps and raises both unique and overlapping concerns. A brief description of each type of cloning is warranted.

Reproductive cloning involves somatic cell nuclear transfer (SCNT). ${ }^{4}$ Using SCNT, the nucleus is removed from an unfertilized oocyte and replaced by the nucleus of a somatic (non-sex) cell of the organism to be cloned. ${ }^{5}$ An electrical pulse is then applied to the oocyte to activate it, much the way a sperm activates an egg by

1 See Ian Wilmut et al., Viable Offspring Derived from Fetal and Adult Mammalian Cells, 385 NATURE 810 (1997). On February 14, 2003, nearly six years to the date of their groundbreaking birth announcement, scientists at the Roslin Institute announced that Dolly had died. Reports reveal that she was euthanized after veterinary examinations showed she had a progressive lung disease. See Dolly the First Cloned Animal Destroyed At Scots Institute, Deutsche Presse-Agentur, Feb. 14, 2003.

${ }^{2}$ See Michael R. Soules, The President's Message: Cloning, 35:1 ASRM News 3 (2001).

3 Michael R. Soules, The President's Message: Cloning, 35:1 ASRM News 3 (2001).

${ }^{4}$ See George E. Seidel, Jr., Cloning Mammals: Methods, Applications, and Characteristics of Cloned Animals, in Human Cloning 28-31 (Barbara MacKinnon ed., 2000).

Id. 
penetrating its surface in the course of natural fertilization. Thereafter, the oocyte develops into an embryo that can be implanted into the uterus of a gestational carrier. ${ }^{6}$ A developing embryo is generally transplanted back to the uterus when it reaches the four-to-eight cell stage, which is approximately two days after fertilization. ${ }^{7}$ Reproductive cloning differs from natural, or sexual, reproduction in that the offspring have the identical genome as the cell donor, rather than a mixture of two genomes from the male and female gamete providers. Dolly is the product of reproductive cloning.

Therapeutic cloning begins with the same steps as SCNT but stops short of implanting the derived embryo into a gestational carrier. ${ }^{8}$ Instead, the embryo is grown to the blastocyst stage, which is beyond the point where it would be implanted into the uterus. ${ }^{9}$ A blastocyst is an embryo at about six days of development. ${ }^{10}$ It is composed of an inner cell mass and a trophectoderm, which is an outer layer of cells destined to become part of the placenta. ${ }^{11}$ The cells from the inner cell mass have the potential to form any cell type of the body and are commonly referred to as embryonic stem cells. ${ }^{12}$ Therapeutic cloning involves removing cells from the intercellular mass and developing compatible stem cells for the organism that provided the nucleus. ${ }^{13}$ A potential application of therapeutic cloning may be the development of tissue for transplantation. If embryonic stem cells can be made to differentiate into liver, nerve, pancreas, or other human cells, such tissue would likely not be rejected by the immune system of the person who supplied the nuclear DNA. ${ }^{14}$ Therapeutic cloning may hold the promise of treating many life-threatening diseases and injuries, but it remains controversial because it requires the destruction of a human embryo.

Embryonic cloning begins with an embryo formed in the "traditional" way, that is by a single sperm penetrating a single oocyte.

6 See Seidel, supra note 4, at 28-31 (Barbara MacKinnon ed., 2000).

See R. R. Saith \& I. L. Sargent, Embryo Selection for Transfer in Human In Vitro Fertilization, 5 Assist. ReP. Rev. 145 (1995). Presumably an embryo created through cloning would likewise be transferred to the uterus at the same early stage of development.

${ }^{8}$ James A. Thomson, Human Embryonic Stem Cells, in The Human EMbryonic Stem Cell Debate 15-16 (Suzanne Holland et al. eds., 2001).

${ }^{9} I d$.

${ }^{10} I d$.

11 Id.

12 Id. at 17.

13 Soules, supra note 2 , at 3 .

${ }^{14}$ Seidel, supra note 4 , at 33-35. 
The cells or blastomeres of the early embryo are then separated and the nucleus from each of these blastomeres is placed in an enucleated oocyte which then becomes an embryo. ${ }^{15}$ Embryo cloning thus produces a finite number of identical offspring, each having the same genome as the original embryo. ${ }^{16}$ Unlike reproductive or therapeutic cloning, embryonic cloning does not involve replicating an existing organism, but rather creates multiple offspring from the donors' combined DNA. Embryo cloning can be used, for example, if a couple has limited gametes and wants to maximize their chance for a successful pregnancy by creating multiple embryos.

Each form of cloning has evoked spirited and often negative reaction. Opponents of reproductive cloning warn of "playing God," threatening the individuality of the cloned person, depriving a cloned child the right to an open future, advancing eugenics by creating super- and sub-human beings, and eroding family relations by creating chaos in the natural ordering of generations. ${ }^{17}$ Therapeutic cloning, like the ongoing debate over the use of human embryonic stem cells for research purposes, invites discussion about the intentional destruction of human embryos. Many feel it is simply wrong to create an embryo for the purpose of destroying it, even if such destruction could produce a good in the form of a cure for disease. Finally, embryo cloning may be viewed as an unnatural and unnecessary manipulation of the human embryo, an intervention that shows disrespect for the integrity of this early form of human life.

In the course of public debate, the differences between the various types of cloning seem to fade; what appears instead are generalized reactions to the concept of cloning as it is popularly understood, primarily as a means of reproduction. ${ }^{18}$ The initial and

15 Id. at 24-28.

16 Id. at 24-27.

17 See Bonnie Steinbock, Cloning Human Beings: Sorting Through the Ethical Issues, in Human Cloning, supra note 4, at 68-84 (containing a review and refutation of the major ethical arguments that have been made against human reproductive cloning); see also Lori B. Andrews, Is There A Right to Clone? Constitutional Challenges to Bans on Human Cloning, 11 HARV. J.L \& TECH. 643, 649-57 (1998) (setting out the potential physical risks, and the psychological and societal impact of cloning humans).

18 Perhaps this is best demonstrated by the passage of H.R. 2505, 107th Cong. ( 2001), which bans all forms of cloning. Specifically, the bill provides that "[i]t shall be unlawful for any person or entity, public or private, in or affecting interstate commerce, knowingly (1) to perform or attempt to perform human cloning . . ." H.R. 2505, at $\$ 302$ (a). The bill later prohibits the development of human embryos through cloning, thus effectively banning therapeutic cloning. Id. at § 302(d). At the time of the House debate, the concept of therapeutic cloning was only beginning to garner public attention. Today it is a more visible issue, due in part to President Bush's announcement in August 2001 about the use of federal funds for human 
continued reaction to reproductive cloning is generally negative, as evidenced by the existing and contemplated bans on the scientific process. ${ }^{19}$ To date, seven states have enacted reproductive cloning bans, ${ }^{20}$ while similar legislation is pending in a majority of American states. $^{21}$ Cloning continues to dominate the national political scene as Senators and Members of the House of Representatives wrestle over the future of reproduction and recuperation using this emerging, yet unnerving, technology. The only consensus our national leaders seem to have reached is that while the merits of therapeutic cloning remain debatable, the practice of reproductive cloning is morally and scientifically unacceptable and should be prohibited. ${ }^{22}$

This Article addresses the worthiness of a ban on human cloning and focuses specifically on the following question: Is a ban on human reproductive cloning moral, legal, or practical? Part I explores the initial and continuing public and political reactions to the concept of cloning as a means of producing children. Because these reactions continue to dominate our emerging legal response to cloning, a review of public sentiment is an integral element in an analysis of cloning law. Interestingly, if one tracks the opinions of public policy makers, as well as members of the general public, it appears that little has changed since Dolly's birth in February 1997 when the possibility of cloning moved closer to a reality-cloning remains a highly unpopular prospect, thus driving the move toward state, national, and international bans ${ }^{23}$ of the practice. Part I posits that cloning resembles other reproductive technologies whose introduction sparked tremendous fear, but whose usefulness ultimately quelled the trepidation accompanying them.

Next, Part II queries whether there is any moral, legal, or practical justification for a ban on cloning. Part II.A. analyzes the

embryonic stem cell research, a technique similar to therapeutic cloning. See, e.g., Carol M. Ostrom, Stem-Cell Research Shows Promise, But Techniques Intertwine with Cloning, Seattle Times, Aug. 29, 2001.

19 See infra notes 31-34.

20 See infra notes 192-98.

21 See infra note 41.

${ }^{22}$ See, e.g., Helen Dewar, Human Cloning Ban Sidetracked; Senate Vote Deals Amendment Second Setback in a Week, WASH. POST, June 19, 2002, at A4 (reporting remarks of Senate Majority Leader Tom Daschle that a bill to allow cloning for research while banning it to produce babies has the support of a majority of senators).

${ }^{23}$ See infra notes $41 \&$ 191-97. An international Convention of the Preservation of the Human Species that would outlaw all efforts to initiate a pregnancy by using human cloning is suggested in George J. Annas et al., Protecting the Endangered Human: Toward an International Treaty Prohibiting Cloning and Inheritable Alterations, 28 AM. J.L. \& MED. 151 (2002). 
moral justifications for cloning bans under two well-established branches of moral philosophy: utilitarianism and deontology. Using the framework of these often conflicting approaches, Part II.A. also explores the rightness and wrongness of human cloning and its prohibition. Ultimately, both philosophies reasonably yield the conclusion that a ban on human cloning cannot be morally justified. If cloning proves to be a safe and effective method of human reproduction, a utilitarian calculus would favor the balance of benefits that cloning could achieve, while a deontologist may find a moral obligation to advance our understanding of the creation of human life.

Part II.B. looks at the legal justifications for cloning bans and specifically raises two potential constitutional challenges to such bans. First, this Part focuses on the assertion that human cloning bans violate protected procreational autonomy by denying individuals the right to choose this unique method of reproduction. Assuming human cloning proves to be a safe and effective technique, it would be considered a viable form of reproduction. Any governmental prohibition on the use of cloning technologies, therefore, would be a substantial infringement of a protected constitutional right. Moreover, Part II.B. argues that current cloning bans are unconstitutionally vague and thus violate the due process rights of patients, scientists, and researchers alike.

Finally, Part II.C. considers the practical aspects of banning human cloning. Advances in animal cloning research already portend the inevitable spillover to the human population, a spillover that is only fueled by the companion interest in developing profitable therapeutics using cloned embryonic stem cells. In addition, ongoing efforts to clone the first human being are well-documented and proceed despite overwhelming opposition to reproduction through cloning. Thus, current scientific advances in cloning let the "genie out of the bottle" and, practically speaking, no law will abate the modern world's interest in the cloning phenomenon. Acknowledging this reality, we must turn our attention away from whether cloning bans are justifiable and focus instead on what effect cloning will have on our society. The search for answers may also help us understand whether we should view cloning as an incremental step in a continuum of assisted reproductive advances or a transgression of nature that will doom the human species. 


\section{GAGING THE RESPONSE TO HUMAN CLONING}

\section{A. Initial Reactions and Actions}

In the days and months following the announcement of Dolly's birth, the federal government acted with uncharacteristic speed to assure the public that human cloning would not become a reality in the near future. On March 4, 1997, a mere ten days after Dr. Wilmut made worldwide headlines, President Clinton issued an Executive Order banning the use of federal funding for human cloning research. $^{24}$ At the same time, the President asked his previously assembled bioethics council, the National Bioethics Advisory Commission (NBAC), to review the legal and ethical issues associated with cloning and to report back to him in ninety days with recommendations on possible federal actions to prevent its abuse. ${ }^{25}$ In June 1997, the NBAC responded to the President's request and issued a report recommending a temporary moratorium on all clinical and research efforts to clone a human being. ${ }^{26}$

The NBAC Report is, by its own admission, a compromise position grounded in the issue of safety, the only area of common agreement among the diverse group of participants. The NBAC agreed that cloning is "not safe to use on humans at this time," and therefore is "likely to involve unacceptable risks to the fetus and/or potential child." ${ }^{27}$ This consensus on safety, coupled with the public's perceived clamoring for protection from science gone awry, would have seemed sufficient to mobilize Congress into passing a total ban on human cloning. In fact, to date no such ban has passed both Houses of Congress, despite the introduction of numerous bills. ${ }^{28}$

${ }^{24}$ Memorandum on the Prohibition on Federal Funding for Cloning of Human Beings, 33 Wrly. Comp. Pres. Doc. 281 (Mar. 4, 1997). At the same time, President Clinton urged the American scientific community to voluntarily refrain from pursuing research in human cloning, at least until such time as a federal advisory commission could study the issue. Id.

${ }^{25}$ Letter from William J. Clinton, President of the United States, to Harold Shapiro, Chair, National Bioethics Advisory Commission, Feb. 24, 1997, reprinted in Cloning Human Beings: Report and Recommendations of the National Bioethics Advisory Commission (1997) (hereinafter NBAC Report).

${ }^{26}$ NBAC Report, supra note 25, at iii-iv (Executive Summary). NBAC also recommended a "continuation of the current moratorium on the use of federal funding in support of any attempt to create a child by somatic cell nuclear transfer." Id. at iii.

${ }_{27} I d$. at 108.

28 See, e.g., H.R. 923, 105th Cong. (1997); S. 1611, 105TH Cong. (1998); S. 1602, 105th Cong. (1998); S. 1599, 105th Cong. (1998). On July 31, 2001 H.R. 2505 passed the House by a vote of 265-162. The bill, and other anti-cloning measures, are currently being considered by the Senate. See infra note 40. For a discussion of 
One might surmise that some legislators worried as early as 1997 that a total ban would also halt valuable research using therapeutic cloning, or that a ban on reproductive cloning could be interpreted as an infringement on women's reproductive autonomy. Perhaps the lack of action is simply the product of ordinary political gridlock. ${ }^{29}$

State legislatures proved far more anxious to outlaw human cloning, as several states enacted cloning bans in the aftermath of Dolly's birth. ${ }^{30}$ California became the first state to ban human cloning by statute, placing a "five-year moratorium on the cloning of an entire human being in order to evaluate the profound medical, ethical, and social implications that such a possibility raises." ${ }^{31}$ The California moratorium was originally set to expire on January 1, 2003, but a new law was enacted in September 2002, instituting a permanent ban on human cloning for reproductive purposes. ${ }^{32}$ In addition to legislative action in the United States, numerous other countries enacted cloning bans, including twenty European nations. ${ }^{33}$

The many efforts to ban the technique of human cloning were not surprising given the intense and nearly universal condemnation of the prospect of human somatic cell nuclear transfer. In a February 24, 1997 Gallup Poll, just one day after Dr. Wilmut's stunning announcement, adults in the United States were asked, "Do you think that human cloning is a good thing or a bad thing?" The results were overwhelming. Eighty-eight percent said cloning was a bad thing, with only six percent finding it a good thing. Similar results were

legislative efforts to ban human cloning, see Elizabeth Price Foley, The Constitutional Implications of Human Cloning, 42 ARIz. L. REV. 649 (2000).

${ }^{29}$ The reasons for congressional inaction on human cloning are far clearer today than they were in the early stages of the debate. In the past year alone, awareness of the use and promise of therapeutic cloning has grown dramatically, due in part to President Bush's August 2001 announcement on federal funding for stem cell research, a related technique that harvests cells from an early embryo. See supra notes 8-14 and accompanying text. By all accounts, the Senate has failed to pass cloning legislation because its members are divided over whether to ban all forms of cloning, or to allow therapeutic cloning but prohibit cloning to produce children. See Dewar, supra note 22, at A4.

30 See, e.g., Cal. Health \& SAFEty Code $\$ 24185$ (Deering 1997); La. Rev. Stat. ANN. § 40:1299.36.3 (West 2000); R.I. GEN. LAWS § 23-16.4-2 (1998); S. 864, 89th Leg., Reg. Sess. (Mich. 1997).

31 Cal. Health \& SAFETy Code $\$ 24185$ (1) (Deering 1997).

32 See S. 1230, Reg. Sess. (Cal. 2001) (California Senate bill extending the operation of the anti-cloning legislation indefinitely, signed into law by Governor Davis on September 22, 2002).

33 See Foley, supra note 28, at 649 n.20 (stating that "Denmark, Estonia, Finland, Greece, Iceland, Italy, Latvia, Luxembourg, Macedonia, Moldovia, Norway, Portugal, Romania, San Marino, Slovenia, Spain, Sweden, and Turkey have banned human closing"). 
obtained when the question was framed in terms of morality. The numbers were identical in response to the question, "Do you think that human cloning would be morally acceptable or would it be morally wrong?" A full eighty-eight percent said cloning would be morally wrong, and only six percent answered that it would be morally acceptable. ${ }^{34}$

Clearly, the initial reactions to the prospect of human cloning were overwhelmingly negative. Editorial pages across the world were replete with dire predictions should the technique make its way into human reproductive circles. ${ }^{35}$ Even Dr. Wilmut, the Scottish scientist who had produced Dolly, labeled the possibility of human cloning "ethically unacceptable," reason in principle why you couldn't do it." ", With such a tremendous consensus on the evils of human cloning, it seemed likely that worldwide efforts to thwart its development would be swift and decisive. But, as in many other arenas, accord does not necessarily translate into action. Though initial reactions were emotional and emboldening, political developments affecting cloning have been fairly sparse, perhaps due in part to the lack of any significant breakthroughs in the field of human cloning. As the twenty-first century dawned, however, the sleeping giant-cloningbegan to wake.

\section{B. Recent Attitudes Toward Human Cloning}

In the six years since Dolly's birth, opposition to human cloning has remained the same. In a November 2001 Gallup Poll, once again eighty-eight percent of respondents said they oppose "cloning that is designed specifically to result in the birth of a human being," while only nine percent approved of such activity. ${ }^{38}$ Congress continues to debate the cloning issue, buoyed by passage of two House Measures on July 31, 2001 and February 27, 2003, banning all varieties of

${ }^{34}$ Roper Center at University of Connecticut, Public Opinion Online (February 24, 1997).

${ }_{35}$ See, e.g., James D. Davis, Cloning News Raises Words of Caution, Sun-SENTINEL, Feb. 27, 1997, at A1; Philip Terzian, Send in the Clones, Providence J.-Bull., Feb. 26, 1997, at B7; Nigel Hawkes, Legal Barriers Will Prevent Apocalypse Now, If Not Later, THE Times, Feb. 26, 1997; Cloning for Good or Evil, N.Y. TimES, Feb. 25, 1997, at A26; Carol McGraw \& Susan Kelleher, Can Cloning Also Give Life to a Soul?, Orange CounT. Reg., Feb. 25, 1997, at A1; Richard Saltus, Created Genetically Equal; Cloning of Adult Mammal Breaks the Scientific Mold, BosTON GLOBE, Feb. 24, 1997, at A1.

36 See Wilmut et al., supra note 1.

37 See Daniel Callahan, A Step Too Far, N.Y. Times, Feb. 25, 1997, at A23.

38 Reported by the American Enterprise Institute for Public Policy Research, No. 2., vol. 13., at 60 (Mar. 1, 2002). 
human cloning, including reproductive and therapeutic forms. ${ }^{39}$ Several bills are currently pending in the Senate, each seeking to ban reproductive cloning, but differing on an additional ban on therapeutic cloning. ${ }^{40}$ At the state level, a majority of jurisdictions are currently considering anti-cloning measures, ${ }^{41}$ and seven states have

${ }^{39}$ H.R. 2505, 107th Cong., (2001) passed the House of Representatives by a vote of 265-162. The House bill imposes criminal penalties on any person or entity that performs or attempts to perform human cloning. The bill defines human cloning as "human asexual reproduction, accomplished by introducing nuclear material from one of more human somatic cells into a fertilized or unfertilized oocyte whose nuclear material has been removed or inactivated so as to produce a living organism (at any stage of development) that is genetically virtually identical to an existing or previously existing human organism." H.R. 2505, at $\$ 301(1)$. The reference to a ban on producing "a living organism at any stage of development" would apply to research or therapeutic cloning which involves producing an early stage embryo from which stem cells are derived. H.R. 534, 108th Cong. (2003), passed the House of Representatives by a vote of 241-155. It likewise criminalizes human cloning.

${ }^{40}$ See S. 2439, 107th Cong. (2002); S. 2076, 107th Cong. (2002); S. 1899, 107th Cong. (2002); S. 1893, 107th Cong. (2002). In addition to the bills pending in the Senate, several bills were introduced over several years in the House of Representatives. See, e.g., H.R. 3495, 107th Cong. (2001); S. 1758, 107th Cong. (2001); H.R. 214, 107th Cong. (2001); H.R. 2608, 107th Cong. (2001); H.R. 2505, 107th Cong. (2001); H.R. 2172, 107th Cong. (2001); S. 790, 107th Cong. (2001); H.R. 1608, 107th Cong. (2001); S. 1644, 107th Cong. (2001); S. 704, 107th Cong. (2001); S. 1372, 107th Cong. (2001); S. 1260, 107th Cong. (2001); S. 2326, 106th Cong. (1999); S. 571, 106th Cong. (1999).

${ }^{41}$ See H.R. 218, 2002 Reg. Sess. (Ala. 2002); H.R. 2108, 45th Leg., 2nd Reg. Sess. (Ariz. 2002); Jt. Res. 38, 2001-01 Reg. Sess. (Cal. 2002); S. 1557, 2001-02 Reg. Sess. (Cal. 2002); S. 1230, 2001-02 Reg. Sess. (Cal. 2002); H.R. 1073, 63rd Gen. Assemb., 2nd Reg. Sess. (Colo. 2002); S. 344, 141st Gen. Assemb., 2nd Yr. (Del. 2002); S. 329, 141st Gen. Assemb., 2nd Yr. (Del. 2002); S. 1164, 104th Reg. Sess. (Fla. 2002); H.R. 805, 104th Reg. Sess. (Fla., 2002); H.R. Res. 1612, 146th Gen. Assemb., Reg. Sess. (Ga. 2002); S. Res. 864, 146th Gen. Assemb., Reg. Sess. (Ga. 2002); H.R. 3693, 92nd Gen. Assemb., 2001-02 Gen. Assemb. (Ill. 2001); S. 493, 92nd Gen. Assemb., 2001-02 Gen. Assemb. (Ill. 2002); S. 138, 112th Gen. Assemb., 2nd Reg. Sess. (Ind. 2001); S. 2118, 79th Gen. Assemb., 2nd Sess. (Iowa 2002); H.R. 2736, 79th Legis., 2002 Reg. Sess. (Kan. 2002); H.R. 138, 2002 Reg. Sess. (Ky. 2002); H.R. Res. 458, 2002 Reg. Sess. (Ky. 2001); S. 1809, 182nd Gen. Ct., 2001 Reg. Sess. (Mass. 2001); S. 1794, 182nd Gen. Ct., 2001 Reg. Sess. (Mass. 2001); S. 1673, 182nd Gen. Ct., 2001 Reg. Sess. (Mass. 2000); S. 192, 182nd Gen. Ct., 2001 Reg. Sess. (Mass. 2000); H.R. 354, 91st Legis., 2002 Reg. Sess. (Mich. 2002); H.R. 361, 2002 Reg. Sess. of Miss. Legis. (Miss. 2001); H.R. 1449, 91st Gen. Assemb., 2nd Reg. Sess. (Mo. 2002); H.R. 1028, 91st Gen. Assemb., 2nd Reg. Sess. (Mo. 2001); H.R. 947, 91st Gen. Assemb., 1st Reg. Sess. (Mo. 2001); H.R. 718, 91st Gen. Assemb., 1st Reg. Sess. (Mo. 2001); H.R. 1067, 97th Legis., 2nd Reg. Sess. (Neb. 2002); H.R. 1464, 2nd Year of the 157th Sess. of the Gen. Ct. (N.H. 2002); H.R. 2040, 210th Legis. (N.J. 2002); H.R. 1379, 209th Legis., 2nd Reg. Sess. (N.J. 2002); S. 542, 209th Legis., 2nd Reg. Sess. (N.J. 2002); H.R. 3978, 209th Legis., 2nd Reg. Sess. (N.J. 2001); S. 7638, 225th Annual Legis. Sess. (N.Y. 2002); H.R. 9292, 224th Annual Legis. Sess (N.Y. 2001); H.R. 2905, 224th Annual Legis. Sess. (N.Y. 2001); S. 1689, 224th Annual Legis. Sess. (N.Y. 2001); S. 1161, 224th Annual Legis. Sess. (N.Y. 2001); S. 670, 224th Annual Legis. Sess. (N.Y. 2001); S. 1552, 48th Legis. 2nd Sess. (Okla. 2002); H.R. 2036, 48th Legis, 2nd Sess. (Okla. 
already enacted legislation banning human reproductive cloning. ${ }^{42}$

Numerous blue-ribbon panels and professional organizations have reported on cloning in recent years; these reports illustrate general opposition to cloning, particularly reproductive cloning. Prominent among these panels is the National Academy of Sciences (NAS), which issued a tentative report in April 2002 addressing the scientific and medical aspects of human reproductive cloning. ${ }^{43}$ In its report, NAS recommends that "human reproductive cloning should not now be practiced [because] [i]t is dangerous and likely to fail." ${ }^{44}$ The report further recommends that there be a legally enforceable ban on the practice of human reproductive cloning. ${ }^{45}$ The NAS position is somewhat akin to that taken by President Clinton's National Bioethics Advisory Commission in suggesting that any ban be reconsidered within five years. ${ }^{46}$ Reconsideration, NAS argues, should be based on new scientific and medical evidence demonstrating that the cloning procedure is "likely to be safe and effective" and "a broad national dialogue on the societal, religious, and ethical issues suggests that a reconsideration of the ban is warranted." ${ }^{47}$

Professional organizations have also responded hesitantly, and sometimes negatively, to cloning. One professional organization that might be viewed as friendly to human cloning is the American Society

15, 2002); H.R. 2142, 48th Legis., 2nd Sess. (Okla. 2002); H.R. 2011, 48th Legis., 2nd Sess. (Okla. 2002); H.R. 3897, 71st Legis. Assemb. (Or. 2001); H.R. 7145, 2001-02 Legis. Sess. (R.I. 2002); S. 820, 114th Sess. of the S.C. Gen. Assemb. (S.C. 2001); H.R. 4408, 114th Sess. of the S.C. Gen. Assembly (S.C. 2001); S. Con. Res. 13, 77th Legis. Assembly (S.C. 2002); S. 1209, 77th Legis. (Tex. 2001); S. 102, 77th Legis. (Tex. 2000); H.R. 2463, 2001 Sess. (Va. 2001); S. 1305, 2001 Sess. (Va. 2001); S. 379, 95th Legis. Sess. (Wis. 2002); H.R. 699, 95th Legis. Sess. (Wis. 2002).

${ }^{42}$ See infra notes 192-97.

43 Committee on Science, Engineering, and Public Policy, Policy and Global Affairs Division, Nat. ACAd. Of Sciences, Scientific And Medical AsPects of Human ReProductive Cloning 6-6 (National Academy Press 2002) (unedited manuscript on file with author) [hereinafter SCIENTIFIC AND MEDICAL ASPECTS OF HUMAN REPRODUCTIVE CLONING].

${ }^{44} I d$.

45 The NAS panel also considered the scientific and medical aspects of therapeutic cloning and concluded that "biomedical research using nuclear transplantation to produce stem cells be permitted." Thus, the panel approved moving forward with therapeutic cloning efforts while supporting a total ban on reproductive cloning, at least until the safety of the technique could be established. Id. at 6-6 - 6-7.

${ }^{46}$ President's Council on Bioethics, Human Cloning and Human Dignity: AN ETHICAL INQUIRY, Executive Summary (July 2002) [hereinafter HCHD REPORT] (calling for a four year moratorium on human cloning).

47 Scientific and Medical Aspects of Human Reproductive Cloning, supra note 43 , at 6-6. 
for Reproductive Medicine (ASRM), a voluntary organization of fertility specialists founded in 1944. ASRM is a multidisciplinary organization whose members include physicians and other health care professionals practicing in the area of reproductive medicine. ${ }^{48}$ Because many of its members could benefit professionally and financially by offering cloning services, one might assume that ASRM would favor minimal restrictions on the technique. Yet, in a November 2000 report from its Ethics Committee, ASRM joined the swell of anti-cloning sentiment. ${ }^{49}$ After discussing the possible ethical arguments for and against reproductive cloning, the ASRM Ethics Committee concluded that "[a]s long as the safety of reproductive SCNT is uncertain, ethical issues have been insufficiently explored, and infertile couples have alternatives for conception, the use of reproductive SCNT by medical professionals does not meet standards of ethical acceptability." ${ }^{, 50}$ Thus, opposition to cloning continues to predominate even among physicians and researchers who are most knowledgeable about the science and potential benefits of this emerging reproductive technology.

The most recent governmental condemnation of human cloning can be found in the newly released report by the President's Council on Bioethics ("the Council"). Created by Executive Order on November 28, 2001, ${ }^{51}$ the Council was charged with advising the President on bioethical issues that "may emerge as a consequence of advances in biomedical science and technology." ${ }^{52}$ The Council chose human cloning as its first topic of inquiry, explaining that " $[t]$ he ethics of human cloning has been the subject of intense discussion in the United States and throughout the world for more than five years, and it remains the subject of heated debate in Congress. ${ }^{~}{ }^{33}$ In July 2002, the Council issued a first report entitled Human Cloning and Human Dignity: An Ethical Inquiry. ${ }^{54}$ The report identifies five categories of concern regarding reproductive cloning and ultimately concludes that "cloning-to-produce-children is not only unsafe but also morally unacceptable, and ought not to be

48 Information about ASRM can be found at its website, http://www.asrm.org (last visited July 18, 2002).

49 The Ethics Committee of the American Society for Reproductive Medicine, Human Somatic Cell Nuclear Transfer (Cloning), in 74 FERTILITY \& STERILITY 873, 875 (2000).

${ }^{50} I d$.

51 Exec. Order No. 13237, 66 Fed. Reg. 59,851 (Nov. 28, 2001).

${ }^{52} I d$. at $\S 2(\mathrm{a})$.

53 HCHD REPORT, supra note 46, at Preface.

${ }^{54}$ See id. 
attempted. ${ }^{55}$ The Council's view on human reproductive cloning was reported as unanimous, in contrast with its views on therapeutic cloning, with some members favoring regulation and others calling for a four-year moratorium on cloning for biomedical research. ${ }^{56}$

What is interesting about these and other measures of public opinion is that we are responding to the prospect of human cloning, not to any existing use of the technology. The adage that "fear of the unknown may be worse than the reality" has certainly dominated the cloning debate. Many commentators look to animal cloning experiments and warn of potential safety concerns that could appear in human attempts, while others conjure up worst case scenarios, portending a "horde of Hitlers" populating our soil and wreaking havoc on our civilized world. ${ }^{57}$ In every case, opinions about cloning rest purely on how one views the future, a mortal impossibility by all known accounts. Whatever the future of human cloning holds, it is still in the future. The emergence of cloning as a new reproductive technology marks a change from past introductions of newly developed reproductive techniques. In past years, we were introduced to new assisted reproductive technologies such as artificial insemination and in vitro fertilization from reports of their success in humans. No media frenzy accompanied the early trials to study and perfect these new methods of conception. ${ }^{58}$ When the technologies were introduced, public reaction was initially negative, as it now is with cloning, but grew increasingly positive as the safety and effectiveness of the new technologies became apparent. ${ }^{59}$ Learning of a technology's promise before hearing of its prospect can have a profound effect on the public's perception of that technology. With cloning, we have had a glimpse of the future and we do not like what we see. Our current efforts to ban future cloning may be grounded in our sincere desire to save the species from certain doom, but we

${ }^{55} I d$. at 6 (Executive Summary). The five categories of concern are: 1) problems of identity and individuality; 2) concerns regarding manufacture; 3) the prospect of a new eugenics; 4) troubled family relations; and 5) effects on society. Id. at 6-7.

${ }^{56}$ Id. at 11-13; see also Sheryl Gay Stolberg, Bush's Bioethics Advisory Panel Recommends a Moratorium, Not a Ban, On Cloning Research, N.Y. TIMES, July 11, 2002, at A21.

${ }^{57}$ See Judith F. Daar, The Future of Human Cloning: Prescient Lessons from Medical Ethics Past, 8 S. CAL. INTERDISC. L.J. 167, 168 n.7 (1998).

${ }_{58}$ The early trials of human in vitro fertilization did garner some comment, but by all objective standards did not rise to the level of public awareness surrounding cloning. See, e.g., Leon R. Kass, Babies by Means of In Vitro Fertilization: Unethical Experiments on the Unborn?, 285 NEw ENG. J. MED. 1174 (1971).

59 See Daar, supra note 57, at 169-79 (describing the early public reactions to artificial insemination by donor and in vitro fertilization). 
must look carefully at whether our efforts can be justified.

\section{CAN A BAN ON Human ReProductive Cloning Be Justified?}

Opposition to human cloning is grounded in many rationales. The most widely held, and perhaps the only legitimate reason for banning cloning, centers on concerns about safety and efficacy. Dolly's birth was widely reported to be the result of 277 failed attempts, ${ }^{60}$ and animal studies continue to reveal pregnancy and neonatal loss, as well as significant structural and functional ailments among those animals who do survive birth. ${ }^{61}$ Though safety concerns are speculative at this point because no attempts at human reproductive cloning have been verified, ${ }^{62}$ these concerns do loom large as we near the brink of the cloning barrier. Virtually all other objections, be they moral, religious, social, or otherwise, seem to contain the same core argument: that human cloning will change the so-called natural order of life, for the worse. ${ }^{63}$ What follows is a discussion of the three primary bases underlying a potential ban on cloning. All pose a simple question: Can a ban on cloning be justified on moral, legal, or practical grounds?

\section{A. Is a Ban on Human Cloning Moral?}

The foray into questions of morality is fraught with controversy

60 See Wilmut et al., supra note 1 , at 811.

61 See infra notes 232-38 and accompanying text.

${ }^{62}$ On April 8, 2002, it was reported that Italian fertility specialist Severino Antinori had succeeded in the first stages of human reproductive cloning. He allegedly told reporters at a conference in the United Arab Emirates that a woman in his research study was, at that time, eight weeks pregnant with a cloned embryo. See First Human Clone 'Is An Arab', DAILY MAIL, Apr. 8, 2002, at 17. As of February 14, 2003, a group known as Clonaid has claimed to have cloned at least three babies born somewhere outside the United States. The first child, a girl named Eve, was claimed to have been born on December 26, 2002, to American parents. Two other cloned babies were allegedly born to parents from Japan and the Netherlands. See Amid Growing Scrutiny, Clonaid Says Third Cloned Baby Has Been Born, Genomics \& GeNeTiCs WKLY., Feb. 14, 2003, at A16.

${ }^{63}$ Examples of these arguments include fear that cloning will undermine human individuality and dignity, encourage parents to treat their children as commodities rather than as human beings, and destroy the integrity of families. See Steinbock, supra note 17, at 68-84. Steinbock summarizes additional moral, ethical and social concerns over cloning including the temptation to play God, the harm of depriving a child of the right to an open future, the nefarious desire to create a sub-human species to serve those of ordinary conception, the fear of eugenics, the deleterious effect on family relations when a parent is both father/mother and sibling, and the deprivation of having two genetic parents. Id. Of course, these arguments against cloning implicitly assume that none of these harms exist under circumstances of ordinary conception, a claim that can hardly be substantiated. 
even when the inquiries are simple and straightforward. The morality of human cloning is, of course, hardly a simple matter. The question of whether human reproductive cloning should be banned has evoked tremendous conflicts among lawmakers, scientists, and perhaps even individual families. Whether a ban on human cloning is morally right or wrong is a seemingly simple query, but one that evades an easy answer. The search for guidance on questions of morality often leads to the realm of moral philosophy. Through the thoughtfulness and eloquence of great thinkers of the past and present, we can begin to formulate a more systematic approach to determining the morality of a cloning ban.

As an initial inquiry, we must answer the question: what is moral philosophy? Two authors who contemplated this question responded that modern moral philosophy is the search for a rational mechanism to resolve moral controversy. ${ }^{64}$ Although somewhat circular, this definition explains that moral philosophy is an attempt to develop standards to evaluate, criticize, and ultimately categorize the distinction between right and wrong conduct. ${ }^{65}$ The term "moral philosophy" is often used interchangeably with the term "ethics," which is defined as the study of standards of conduct and moral judgment. $^{66}$

Contemporary moral philosophy is comprised of competing theories, each advancing the supremacy of a distinct interest or theme. There are numerous well-developed ethical theories, ${ }^{67}$ however, the following two theories stand out as particularly useful in evaluating the morality of a ban on human cloning: utilitarianism and deontology. Briefly stated, utilitarianism is a consequence-based theory, holding that actions are right or wrong according to the

${ }^{64}$ JefFrie Murphy \& Jules Coleman, The Philosophy of LaW: An Introduction TO JURISPRUDENCE 73 (1984). I have previously discussed the application of moral philosophy to another bioethical dilemma, selective reduction of multiple pregnancy. Some of the foundational discussion about moral philosophy derives from that work. See Judith F. Daar, Selective Reduction of Multiple Pregnancy: Lifeboat Ethics in the Womb, 25 U.C. DAVIS L. REV. 773, 823 (1992).

${ }^{65}$ I derive this explanation of Murphy and Coleman's definition of moral philosophy, supra note 64, from C.E. HARRIS JR., APPLYING MORAL THEORIES 2 (1986).

${ }^{66}$ HARRIS, supra note 65, at 2. Harris argues that moral philosophy is synonymous with ethics because it involves a set of specifically elaborated principles of ethics. Id.

67 See Tom L. Beauchamp \& James F. Childress, Principles of Biomedical Ethics 44 (4th ed. 1994). In their groundbreaking work, Beauchamp and Childress concentrate on several types of ethical theories, including utilitarianism, Kantianism, character ethics, liberal individualism, communitarianism, the ethics of care, casuistry, and common-morality accounts. While each of these theories could be applied to the morality of a cloning ban, I have focused on the two theories that I believe yield the most interesting contrast in analysis. 
balance of their good and bad consequences. ${ }^{68}$ Deontology, in contrast, assesses whether an action has independent moral weight. ${ }^{69}$ Deontologists believe that features of an action other than, or in addition to, consequences make that action right or wrong. ${ }^{70}$ These somewhat competing ethical theories provide an interesting starting point for assessing the morality of a ban on human cloning.

\section{Banning Human Cloning: A View From Utilitarianism}

The essential core of utilitarianism is the idea that human actions and practices should be evaluated ultimately in terms of their tendencies to advance the general welfare or social good. Put another way, utilitarianism seeks to have human actions result in the happiness or well-being of a majority of persons. It is often explained by reference to the mantra, "The greatest happiness for the greatest number." "' It advocates following the course of action that leads to the best possible consequences. Thus, the ends are permitted to justify the means. In the cloning context, utilitarianism would hold that cloning should be permitted if it would maximize overall social welfare, even if in the process it would be damaging to some individuals.

To begin a utilitarian analysis, it is essential to marshal the good and bad consequences that cloning might produce. It is important to note, however, that any perceived benefits or harms are at this point speculative, as we have not yet succeeded in cloning a human being. The speculative nature of the consequences of cloning points out the difficulty in assessing the moral rightness or wrongness of the technique. Our application of utilitarianism, or any other moral theory, relies on having some grounding in the action to be studied. In the case of cloning, we must juxtapose the anticipated good outcomes with the perceived bad consequences. Once the science of cloning begins to emerge, we may find ourselves shifting the utilitarian analysis to meet the realities of the technique. ${ }^{72}$

$68 \quad I d$. at 47.

${ }^{69} \quad I d$. at 56-57.

${ }^{70} I d$. at 56.

71 See Murphy \& Coleman, supra note 64, at 74 (quoting Jeremy Bentham, PRINCIPLES OF MORALS AND LEGISLATION (1789)).

${ }^{72}$ In fact, utilitarians view themselves as responsive to changing social and scientific conditions. They believe that actions should be evaluated in light of existing social conditions, thus happiness is measured relative to prevailing social norms. BEAUCHAMP \& CHILDRESS, supra note 67, at 48-49. 


\section{a. Possible Benefits of Reproductive Cloning}

The ethics of utilitarianism could justify a ban on human cloning if the balance of bad consequences outweighs the good consequences. Much has been written about the potential good and bad consequences that cloning portends, thus what follows is a brief overview of the anticipated consequences of human SCNT.

Identifying the possible benefits of cloning is the first step. If cloning proves a safe and effective method of reproduction, it could aid couples and individuals in several ways. Couples who are refractory to current infertility treatment would be able to have a genetically related child through cloning. For example, couples in which both the male and female lack gametes ${ }^{73}$ are unable to produce a child without the aid of gamete donors. Cloning would allow such a couple to experience the joys of parenting a child whose genes derive from one member of the pair. In this capacity, cloning would join a growing spectrum of assisted reproductive technologies that currently aids tens of thousands of individuals in realizing their dreams of parenthood. ${ }^{74}$ Because of its complexity and likely expense, it would serve as a last resort for most couples who desire to parent a genetically-related child, but nevertheless it would likely bring tremendous happiness to those couples who successfully avail themselves of the technique.

In addition to aiding infertile couples, cloning could also be used to avoid transmission of deleterious genetic traits to offspring. In light of our growing familiarity with genetically-based disease processes, we are increasingly aware that the key to maintaining our health lies more in the past than it does in the future. The Human Genome Project has revealed the genetic bases of many diseases and is now beginning to pinpoint the exact location of genes thought to be responsible for these ailments. ${ }^{75}$ If a couple is aware that one

73 This could occur, for example, if the woman lacked ovaries due to treatment for a disease process, and the man lacked sperm due to radiation therapy to treat testicular cancer. If the woman still had a uterus she could gestate the cloned embryo and also experience the wonders of pregnancy.

${ }^{74}$ In the year 1998 alone, assisted reproductive technologies were the means of conception in the births of 29,128 children. The technologies include in vitro fertilization and embryo transfer, gamete intrafallopian transfer, and zygote intrafallopian transfer. See Assisted Reproductive Technology in the United States: 1998 Results Generated From The American Society for Reproductive Medicine/Society for Assisted Reproductive Technology Registry, 77 FERTILITY \& STERILITY 18-19 (2002).

${ }^{75}$ See Michael J. Smith, Population-Based Genetic Studies: Informed Consent and Confidentiality, 18 Computer \& High TeCH. L.J. 57, 62 (2001) (reporting that "over 5,000 human disorders are known to have a genetic basis and over 1,000 of those disorders have been mapped to specific regions of the genome"). 
member is a carrier for a genetically-linked disease, cloning may be a sure way to avoid passing that gene to the couple's offspring. As with infertility treatment, cloning may not necessarily be the first choice for a couple in this position, as current technologies offer numerous alternatives to prospective parents wishing to avoid deleterious gene transmission. In addition to the use of donor gametes, couples can use preimplantation genetic diagnosis (PGD) to learn about the health of their embryos before they are implanted into the uterus. ${ }^{76}$ Using PGD, the couple can select for implantation only the unaffected embryos in an effort to maximize the health of their child. Cloning, however, may be more attractive to couples wishing to avoid deleterious gene transmission because it does not involve the deliberate destruction of affected embryos. In the end, cloning could benefit those couples who wish to avoid passing on one partner's genome because of its health implications. ${ }^{77}$

A third possible benefit of cloning would be to assist single individuals and same sex couples in their efforts to reproduce. These prospective parents may wish to procreate without the aid and potential entanglement of gamete donors. ${ }^{78}$ For single individuals and same sex couples wishing to parent a genetically-related child, cloning offers benefits that are unmatched by current reproductive technologies. For this group, the use of donor gametes may be particularly unattractive because of its potential to raise parentage issues. Lesbian couples that use artificial insemination by donor (AID) risk sperm donors' paternity claims once the child is born. In some cases, courts uphold these claims, warning that AID donors relinquish their parental rights only if the recipient woman follows a statutory protocol surrounding the insemination. ${ }^{79}$ Single and gay

\footnotetext{
${ }^{76}$ Y. Verlinsky et al., Preimplantation Genetic Diagnosis: An Integral Part of Assisted Reproduction, 17 J. Assist. REPROD. \& GENETICS 75, 76 (2000).

77 Realistically we must bear in mind that the lack of known deleterious genes in the unaffected partner does not mean that the individual lacks genes related to disease processes. We are in the infancy stage of our knowledge of genes and their relationship to health. The use of cloning or PGD to avoid transmission of certain genes may still produce children who suffer from genetically-based illnesses and syndromes.

${ }^{78}$ Of course, in the case of males who wish to have a genetically related child through cloning, a gestational carrier will be necessary to gestate the embryo to term. But even for these males, the absence of an egg donor may be important to avoid possible parental claims in the future.

${ }^{79}$ See, e.g., Jhordan C. v. Mary K., 179 Cal. App. 3d 386 (1986) (refusing to apply a statute, providing that a sperm donor is treated in law as if he were not the natural father of the child conceived, because a donor provided sperm directly to the mother rather than to a licensed physician, as specified in statute); C.O. v. W.S., 639 N.E.2d 523 (1994) (holding that failure to comply with statutory medical
} 
men also face claims by egg donors and genetic surrogates whose link to the child may also entitle them to parental rights. Cloning may alleviate some of these worries by eliminating gamete donors from the procreation equation.

Another beneficial use of cloning would be to aid parents who have suffered the loss of a child. This use would require that parents preserve some number of cells from their child, either before the child dies or even shortly after death. ${ }^{80}$ Of course, the cloned child would not be the same human being as the deceased child, but his or her genetic similarity to the passed sibling may provide enormous solace to the parents. In fact, reproductive cloning to respond to the loss of a child has motivated couples to support underground cloning efforts in the United States. ${ }^{81}$ Clearly, these parents believe that cloning would be a benefit to them. Critics wonder, however, whether the cloned child, even if born healthy, would benefit from conception in this manner and under these circumstances. ${ }^{82}$ Would the parents harbor unrealistic expectations of the child that would negatively impact that child's life? Perhaps a utilitarian analysis would weigh the parents' happiness and the value attributable to the child being born against the child's unhappiness. If the overall benefit is thought to outweigh the harms, an uncompromising utilitarian would approve of cloning in this circumstance. ${ }^{83}$

In summary, at least four groups could reap benefits from reproductive cloning: infertile couples refractory to treatment with

requirements for artificial insemination prevents a mother from invoking the statute to obtain dismissal of her sperm donor's complaint to determine paternity, custody, support, and visitation); cf. Lamaritata v. Lucas, 823 So. 2d 316 (Fl. Dist. Ct. App. 2002) (holding a sperm donor was not a parent and had no parental rights or responsibilities under a statute governing artificial insemination).

${ }^{80}$ The idea of post-mortem reproductive cloning is no longer strictly a science fiction idea. In 2001, scientists announced that they had successfully cloned a calf from a cow that had been dead for 48 hours. Using a cooling method, the cow's cells were removed two days after death and then the nuclei were extracted and injected into enucleated egg cells. See Rebecca McCarthy, UGA Clones Calf from Dead Animal, Atlanta J. \& Const., Apr. 26, 2002, at 1A.

${ }^{81}$ See infra notes 296-301 and accompanying text.

82 Additional concerns surround the scenario where a child dies from an inheritable disease and the parents choose to clone that child with the hope that new treatments will be available for the later-born child. In this situation, parents are purposefully causing the birth of a child who is highly likely to suffer during life and experience a premature death. While one might question the competency or compassion of parents who pursue this course of action, nothing in our current law prevents parents with known genetic disease markers from conceiving children and risking transmission to these offspring.

${ }^{83}$ I borrow the term "uncompromising utilitarian" from BEAUCHAMP \& CHILDRESS, supra note 67, at 49 . 
other assisted reproductive technologies; couples wishing to assure avoidance of a deleterious genetic trait; single and same sex couples who eschew the use of gamete donors, but who wish to have a child that is genetically related to them; and parents who wish to clone a deceased child. These individuals would argue that cloning is uniquely capable of providing them the parenting opportunities they seek. A ban on cloning would significantly harm these individuals because there are no alternatives that fulfill their specific desires. The overall utility of cloning, however, can only be evaluated by weighing both benefits and harms. The next section explores some of the counterbalancing perceived harms of reproductive cloning.

\section{b. Possible Harms of Reproductive Cloning}

When Dolly's birth was first announced in 1997, the popular press was replete with dire warnings about the evils of human cloning. ${ }^{84}$ In the past six years, numerous scholars, commentators, and policymakers have weighed in on the cloning debate, with the vast majority counseling against the use of human reproductive cloning. ${ }^{85}$ What follows is a modest attempt to highlight a few of the many objections to this emerging reproductive technology.

First, and perhaps most importantly, there are tremendous concerns over the safety and efficacy of human cloning. ${ }^{86}$ To date, despite claims to the contrary we have seen no evidence of any human being conceived through SCNT. ${ }^{87}$ As a result, we do not know what that process would yield in the human reproductive setting. Moreover, animal studies reveal that in some cases the cloned offspring suffer from health problems related to structural and functional abnormalities. ${ }^{88}$ While we do not yet know how the data collected on animals will translate to the human population, at the very least we know that the safety of human cloning is not assured. Of course, the safety of reproduction in any form is never certain, but at least with existing technologies we are familiar with the risk profiles associated with each technique.

A second harm often cited is the threat cloning poses to the

${ }^{84}$ See supra note 35.

85 See supra notes 17-57 and accompanying text.

${ }^{86}$ Sheryl Gay Stolberg, Visions: Biology: A Genetic Future Both Tantalizing and Disturbing; A Small Leap to Designer Babies, N.Y. TIMES, Jan. 1, 2000, at E7 (reporting a retired Harvard Biology Professor's concern that "the risk of creating deformed babies is too great").

${ }^{87}$ See supra note 62.

88 See infra notes 231-38 and accompanying text. 
individuality of the cloned child. ${ }^{89}$ The worry is that society would view the child as a mere replica of the cell donor and, therefore, undervalue the child's unique selfhood. Whatever talents or idiosyncrasies attached to the donor would be expected of the child, with no care paid to allowing the child to develop an individualized personality. Parents might expect the child to make the same life choices made by the cell donor and might mete out severe repercussions if the child fails to satisfy these expectations. ${ }^{90}$ On a grander scale, cloning might threaten the individuality of the human race. If cloning becomes widespread, it would reduce the number of unique genomes born in our world, creating classification of persons according to the perceived worth of their genes. We would cease valuing individuality and instead fixate on the predetermined genetic destiny attached to the cloned person.

An oft-cited response to concerns about individuality is that a clone would be born as an infant in a different familial setting and in a different historical time frame. ${ }^{91}$ Unique circumstances and events would shape the child's life, as cloning certainly does not expose the child to the formative environment of the cell donor. The child's future would be as open as any naturally conceived child, both of whom may have parents who harbor great expectations for their children. A parent's expectations for his or her child would probably not change in a cloning scenario, as expectations are often based on the parent's own accomplishments and failures. Whether those accomplishments and failures derive from one genome or two would not likely alter parents' attitudes toward their children. Moreover, concerns that the same genetic diseases plaguing the cell donor will also affect the clone are not necessarily well-founded. Advances in genetic diagnosis and gene therapy have progressed at a rapid pace

${ }^{89}$ HCHD REPORT, supra note 46, at Executive Summary; see also Carolyn Wilson, Statement in the Ad Hoc Committee on the International Convention Against the Reproductive Cloning of Human Beings, February 26, 2002, 18 Iss. IN L. \& MED. 187 (2000).

90 One author has labeled this phenomenon as depriving a child of "a right to an open future." See Joel Feinberg, The Child's Right to An Open Future, in Whose ChILD? Children's Rights, Parental Authority, and State Power 124 (W. Aiken \& H. LaFollette eds., 1980); see also Dena S. Davis, Genetic Dilemmas and the Child's Right to an Open Future, 28 RuTGERS L.J. 549 (1997). This argument rests on a notion of genetic determinism, that one's genome determines one's future. A child with a duplicated genome would lack the opportunity to determine his or her own future, or at the very least would be aware of the life choices and life struggles that afflicted the cell donor. This knowledge alone would limit the "open future" for cloned individuals who might be herded into the same life path followed by their predecessors.

${ }_{91}$ See Michael A. Goldman, Human Cloning: Science, Fact and Fiction, 8 S. CAL. INTERDISC. L.J. 103 (1998). 
in the past ten years and are predicted to accelerate with each passing day. ${ }^{92}$ We have learned much about the genetic bases of certain diseases, such as coronary artery disease and hypertension, which are diseases that are highly responsive to newly developed therapies and studied lifestyle changes. Since many gene-linked diseases do not develop until adulthood, a cloned child could reasonably assume that a treatment for his or her particular disease would be available when needed.

A third harm expressed about cloning is the threat of commodification of children. ${ }^{93}$ If and when cloning becomes available for reproduction, it will likely enter the market at an extraordinarily high price. The expenses surrounding human cloning are already a topic of discussion, and these costs are out of reach for the vast majority of prospective parents. ${ }^{94}$ For those few wealthy individuals who do avail themselves of the emerging technology, there is concern that they will treat their cloned children as commodities, rather than as individual human beings, because their births were orchestrated at an enormous financial cost. ${ }^{95}$ Parents, it is argued, will expect a return on their investment much in the way any investor seeks profit, and thus will be intolerant of any perceived imperfection in their "product."

It may be worth noting that similar concerns have been raised over other reproductive scenarios. These include surrogate parenting arrangements in which a woman is paid to gestate another couple's embryo, and the creation of embryos using donor gametes in which prospective parents pay for gametes that meet their specifications. ${ }^{96}$ Both of these arrangements involve the expenditure

92 See U.S. Gene Therapy Markets, reported in Medicine \& HeALTH's Business AlerT 13 (2002) (predicting in a report released on February 11, 2002 that gene therapy products will be introduced worldwide in 2004 and will generate approximately $\$ 125$ million in annual revenues; these products include 134 genomic oncology drugs currently in Phase II clinical trials and seven drugs in Phase III trials) (on file with author).

93 E.D. Pellegrino, Balancing Science, Ethics, and Politics: Stem Cell Research, A Paradigm Case, 18 J. Contemp. Health L. \& Pol'y 591, 609 (2002) (noting that "the likelihood of extension of commodification to human cells is unfortunately high").

${ }^{94}$ See James A. Haught \& Tara Tuckwiller, Cloning Effort Hidden in West Virginia Town; Father Wanted to Duplicate Dead Son, WASH. Times, Aug. 14, 2001, at A1 (reporting payment of $\$ 500,000$ by a Charleston lawyer to a cloning group to clone his dead son).

${ }^{95}$ John A. Robertson, Liberty, Identity, and Human Cloning, 76 TEx. L. REv. 1371, 1399 (1998).

${ }^{96}$ The costs associated with these two scenarios are hardly accessible to the average-salaried individual. The average fee paid to a gestational carrier is $\$ 10,000$. See Johnson v. Calvert, 851 P.2d 776, 778 (Cal. 1993) (describing a contract for 
of significant funds, as does the use of assisted reproductive technologies in general. The average cost for a single treatment using in vitro fertilization and embryo transfer is between $\$ 8,000$ and $\$ 10,500,{ }^{97}$ as compared to the absence of expenses associated with natural conception. Yet nearly two decades of experience with collaborative and assisted reproduction, a process in which couples often spend their life savings in pursuit of parenthood, have not yielded a study showing that these parents regard their children as commodities. In fact, psychological profiles conducted on the children of assisted reproduction show they are no different from their naturally conceived counterparts. ${ }^{98}$

A final harm worthy of inclusion is the prediction that cloning will advance eugenics in our society. Opponents postulate that through cloning it will be possible to develop both super- and subhuman individuals to meet society's needs, creating a class system beyond any naturally occurring division among the people of the world. The clear distinctions among individuals will lead us to revere and shun certain genotypes, perhaps ultimately leading to the enslavement or destruction of the lesser class. ${ }^{99}$ What is so very sad about this Doomsday scenario is that history has proven that we do not need cloning to practice eugenics in our society. The examples abound, including the Holocaust in World War II Germany, ethnic cleansing in the former Yugoslavia in the late 1990s, and the implementation of forced sterilization statutes to weed out "mental defectives" from American society in the 1920s. Justice Holmes' words of seventy-five years ago still ring eerily from his opinion in Buck v. Bell, when the Court upheld a Virginia statute allowing

gestational services calling for payment of $\$ 10,000$ to the gestational carrier). In the case of egg donors, there have been reports of couples willing to pay upward of $\$ 100,000$ to an egg donor who meets their highly specific criteria. See Martha FraseBlunt, Ova-Compensating?; Women Who Donate Eggs to Infertile Couples Earn a Reward B But Pay a Price, WASH. Post, Dec. 4, 2001, at F1 (reporting on a half-page advertisement in the Stanford Daily offering $\$ 100,000$ for the eggs of a donor "with proven college-level athletic ability").

${ }^{97}$ See Edward G. Hughes \& Mita Giacomini, Funding In Vitro Fertilization Treatment for Persistent Subfertility: The Pain and the Politics, 76 FERTILITY \& STERILITY 431, 437 (2001).

${ }^{98}$ See id. at 437 (reporting that no differences have been noted between IVF offspring and the general population up to the age of thirteen years).

${ }_{99}$ See George J. Annas et al., Protecting the Endangered Human: Toward an International Treaty Prohibiting Cloning and Inheritable Alterations, 28 AM. J.L. \& MED. 151, 153 (2002) (describing human cloning as a crime against humanity "by taking human evolution into our own hands and directing it toward the development of a new species, sometimes termed the posthuman") (citing to FrANCIS FUKUYAMA, OUR Posthuman Future: Consequences of the Biotechnology Revolution (2002)). 
involuntary sterilization of mental defectives because "three generations of imbeciles are enough." 100

Sadly, ordinary conception has already produced men capable of ferocious inhumanity unaided by any reproductive technology. Cloning will likely not provide any greater opportunity for manipulating our offspring than we currently enjoy. ${ }^{101}$ Using preimplantation genetic diagnosis, we can screen embryos for genetic traits, either deleterious or benign, and select those traits we find most desirable. Moreover, the opportunities for collaborative reproduction allow parents to choose the phenotypes and genotypes that will combine to produce their child. Nothing in our current law prevents parents from selecting egg and sperm donors of a particular stature, intelligence, race, etc. in order to attempt to "engineer" their children.

To date, we have seen parents using the option of donor gametes in order to maximize the well-being of their children, with most families selecting donors who resemble them in appearance and family background. ${ }^{102}$ The children of assisted reproductive technology (ART), though they may have been engineered to some extent, are welcomed by their parents as any newborn is welcomed. ${ }^{103}$ There is no logical reason why a cloned child would not receive the same treatment. Children of cloned conception will be born into the world as any other child. Their parents' instincts for nurturing will or will not take hold, making these children no more or less likely than any other children to experience the joys and sorrows of life.

The above discussion of the potential benefits and harms of human reproductive cloning, along with some of the

100274 U.S. 200 (1927). For a thorough discussion of the history of the American branch of the international eugenics movement, see Paul A. Lombardo, "The American Breed": Nazi Eugenics and the Origins of the Pioneer Fund, 65 ALB. L. REv. 743 (2002).

${ }^{101}$ An interesting twist that emerges from experiments surrounding animal cloning is that cloned animals do not necessarily look like their genetic parent. In the case of "cc" the cat, cloned by researchers at Texas A\&M University in December 2001, the cloned animal had a totally different fur pattern from her genetic mother. The reasons for this difference in phenotype can be explained by uterine influences during gestation, including the position of the fetus in the womb. See Wes Allison, How Many Lives Now?, St. Petersburg Times, Feb. 24, 2002, at 1A. While we still do not know whether findings in cloned animals will translate into humans, the experience with "cc" reinforces the notion that cloning is not replication; each individual animal takes on its own characteristics that make it a unique being.

102 See Frase-Blunt, supra note 96 (explaining that couples seeking egg donors "just want to find someone like themselves").

${ }^{103}$ Janet L. Dolgin, Suffer the Children: Nostalgia, Contradiction, and the New State of Reproductive Technologies, 28 ARIz. ST. L.J. 473, 504 n.119 (1996). 
counterarguments attendant to these assertions, is an essential starting place for a utilitarian analysis. But a mere listing of utilities and disutilities does not answer the question of whether cloning is a morally correct act. In the case of cloning, balancing the benefits and harms does not reveal a clear champion. Both sides have merit; both demonstrate the happiness and angst that cloning can engender. In addition to difficulties in discerning the morality of an action when the benefits and harms appear to be in equipoise, utilitarianism suffers other drawbacks as an ethical theory. Those drawbacks are as applicable to cloning as to any other act where ethics are in question.

\section{c. Criticisms of Utilitarianism as a Moral Theory}

All moral theories offer strengths and weaknesses in their ability to assess the moral rightness of human actions. Perhaps the greatest strength of utilitarianism is its apparent simplicity. Once the good and bad consequences of an action are assessed, a utilitarian can pronounce the action moral or immoral simply by balancing these findings. Of course, making moral judgments is never easy, and this simplistic description of utilitarianism reveals at least two problems with the theory as a fully adequate measure of morality. Briefly stated, utilitarianism has the potential to overstate benefits on the one hand, while disregarding detriments on the other.

The problem with measuring the benefits of a certain action is that the notion of benefit is highly imprecise. Utilitarians share the conviction that human actions should be assessed morally in terms of their production of maximal value, but they disagree over which values are most important. ${ }^{104}$ For some utilitarians, the value of happiness should be the sole measure of utility, ${ }^{105}$ while others argue that values other than happiness have intrinsic worth. ${ }^{106}$ Among these other values are knowledge, health, and personal autonomy. ${ }^{107}$ In the case of cloning, if happiness is the sole measure of utility, then the

104 BEAUCHAMP \& CHILDRESS, supra note 67, at 48.

105 The two most noted philosophers who hold this view are Jeremy Bentham and John Stuart Mill, often referred to as "hedonistic utilitarians" because they conceive utility entirely in terms of happiness and pleasure, two broad terms they treat as synonymous. Id. (citing JEREMY BENTHAM, AN INTRODUCTION TO THE PRINCIPLES OF Morals ANd Legislation 11-14, 31, 34 (1970); John STUART Mill, Utilitarianism 207, 210, 214, 234-35 (Univ. of Toronto Press 1969)).

${ }^{106} I d$.

107 Additional values include friendship, beauty, achievement and success, understanding, enjoyment, and deep personal relationships. Id. (citing G.E. Moore, Principia Ethica 90 (1903)); see also James Griffen, Well-Being: Its Meaning, MEASUREMENT AND MORAL IMPORTANCE 67 (1986). 
happiness of the parents derived from rearing a cloned child would outweigh the difficulties experienced by the child because of physical or psychological infirmities. ${ }^{108}$ The two parents' happiness would also likely outweigh any generalized concerns over the impact of cloning on society, because individual happiness trumps speculative societal harms.

In addition to imprecision in the measure of utility, an objection to utilitarianism is the subjective nature of benefit. An individual can express a preference that would be viewed as morally unacceptable under prevailing social norms, yet that individual will derive happiness by exercising that preference. Here, the theory of utilitarianism must struggle with determining whether individual preferences should be the measure of utility, or whether preferences must fit within prevailing norms. ${ }^{109}$ For example, if a parent cloned a child solely to serve as a solid organ donor for an ill sibling, we might condemn that action and seek to prevent it. ${ }^{110}$ In our society, we value parents who embrace each of their children for his or her individual self-worth. A parental preference that would involve killing a child to save another should cause us to question the soundness of a utility equation where three people are benefitted and only one is harmed, when that harm involves unacceptable moral (and legal) consequences.

As noted above, utilitarianism is problematic in its relative and absolute assessment of benefit. Perhaps even more troubling, however, is its dismissal of harm and tendency toward a tyranny of the majority. Since the principles of utilitarianism dictate that the interests of the majority are to override the rights of the minority, the harms suffered by a few would be dismissed as unimportant in the overall utilitarian calculus. In a cloning scenario, the harms may be profoundly damaging to a few individuals, so much so that their objections should not be disregarded. If cloning produces children who are severely impaired and who suffer greatly during their

108 Some might argue that a cloned child derives happiness just from being born, even if the child experiences suffering during his or her life. This happiness, combined with the parents' happiness at the opportunity to rear a cloned child, could outweigh the unhappiness experienced collectively by the parents and the child, deeming reproductive cloning a morally acceptable act when measured in terms of happiness alone.

109 See BEAUCHAMP \& CHILDREss, supra note 67, at 53.

110 This scenario should be contrasted with one in which parents conceive a child to aid an ailing child, but also intend to nurture that new child as an integral part of their family. In these cases, the newly conceived child is subjected to minimal harm and would presumably receive the same love and nurturing bestowed upon the ailing child. 
shortened lifetimes, their conception could be morally justified using utilitarian logic if their parents, and the physicians and researchers who helped develop the technology for their birth, derive great happiness from the accomplishment of creating a cloned human being. In thinking about whether a ban on human cloning can be morally justified, it is difficult to dismiss the potential harm to the cloned individuals, even if the vast majority of those affected incur tremendous benefit. ${ }^{111}$ Conversely, if only a few members of society fear the repercussions of cloning, and the vast majority, including the cloned individuals themselves, are greatly benefited, overriding the harms anticipated by those who are not directly affected by the technology may be morally justified under utilitarian theory.

In the end, assessing the morality of a ban on human cloning is difficult to accomplish using utilitarian principles because the science has yet to reveal any actual benefits or harms to human beings. The danger with proceeding to develop the science is, of course, that the harms to cloned individuals will overwhelm any benefits. For this reason alone, many have supported a total ban on human reproductive cloning. ${ }^{112}$ But as noted in Part II.C., whether or not a ban is enacted in the United States or abroad, cloning researchers will continue to pursue the holy grail that human cloning has become. Perhaps the better approach is to minimize the harms by dedicating the most talented and highly organized scientific teams to unravel the cloning mysteries, rather than allowing underground and sporadic efforts to cause unnecessary pain and suffering.

\section{Banning Human Cloning: A View From Deontology}

The moral theory of deontology holds that the moral worth of an individual's action depends exclusively on the moral acceptability of the rule on which that person acts. ${ }^{113}$ Thus, deontologists look not to the consequences of an action, but rather to whether the act conforms to an overriding moral duty. An act would be considered morally right if it fulfilled a morally acceptable principle; an act would be judged wrong by a deontologist if it violated a moral duty or principle. The deontological ethic is closely associated with

111 The following vivid illustration nicely describes the problem of the tyranny of the majority in a utilitarian calculus: A healthy young patient goes to her physician for a routine physical examination only to be killed for her organs so that five dying patients can be saved. Utilitarianism would likely favor such action because one dead is better than five dead. See Judith J. Thomson, Comment, The Trolley Problem, 94 Yale L.J. 1395, 1406-15 (1985).

112 See supra PART I.

113 BeAUCHAMP \& Childress, supra note 67, at 57-58. 
Immanuel Kant ${ }^{114}$ and his moral rule or categorical imperative: "Act in such a way that you always treat humanity, whether in your own person or in the person of another, never simply as a means, but always at the same time as an end." 115 Put in a more contemporary idiom, this imperative comes to the following: "All rational persons have a right not to be used without their consent even for the benefit of others." ${ }^{\text {"16 }}$ The application of a deontological ethic to a ban on human cloning requires defining the relevant rules and duties that could potentially be advanced or violated by such a prohibition of conduct. A ban on human cloning might be viewed as morally right because it fulfills a duty that human beings have to avoid inflicting harm to others. Since some of the early cloning studies conducted on animals showed that some animals suffered life-threatening impairments, ${ }^{117}$ a deontologist might argue that attempting human cloning is immoral because it may cause harm to cloned children, thus violating a moral duty to maximize the well-being of our offspring. Under a different set of scientific assumptions, however, human cloning could be seen as morally acceptable. If cloning proves safe and effective, couples who wish to avoid transmission of a deleterious genetic trait may be fulfilling the moral duty of maximizing their child's welfare by utilizing the technique.

Deontology, like utilitarianism, fails to provide a full and adequate theory of the moral life. ${ }^{118}$ Criticisms of deontology focus on the nature and hierarchy of the moral duties that are the foundation of this moral theory. ${ }^{119}$ Two specific problems that seem relevant to the cloning dilemma are the problem of conflicting obligations and the fallacy of moral absolutism. Both of these problems allow us to think deeper about the moral obligations we believe should motivate human conduct, as well as the obligations that actually do cause us to act.

114 Id. at 56.

115 Immanuel Kant, Groundwork of the Metaphysics of Morals 96 (H.J. Paton trans., 1964) (emphasis in original). For a discussion of autonomy, rights, and the treatment of persons as ends in themselves in Kantian theory, see MURPHY \& COLEMAN, supra note 64 , at 78-86.

116 Murphy \& Coleman, supra note 64, at 83.

117 Rosie Mestel, Dolly's Death Resurrects Debate on Cloning Ethics, L.A. Times, Feb. 16, 2003, at A1 (noting that "[a] growing number of studies suggest that clones-even the ones that make it to adulthood-may carry within them subtle genetic abnormalities that could cause medical problems later in life").

118 BEAUCHAMP \& CHILDRESS, supra note 67, at 60.

119 Id. at 60-62. 
a. Deontology and the Problem of Conflicting Obligations

The problem of conflicting obligations arises when an individual faces a choice of action that will result in the fulfillment of one moral duty while another is violated. ${ }^{120}$ Since deontology makes all moral rules absolute, whatever course of action is taken will necessarily involve violation of some moral duty. For example, if an only child was involved in an automobile accident and suffered from kidney failure as a result, the parents might make the decision to clone the sick child to conceive and rear another child who could serve as a kidney donor at an appropriate age. Here the parents would face two competing obligations: the duty to maximize the well-being of their child, and the duty to avoid treating any child as a means to an end. The parents might argue that cloning would not violate the latter duty in this case because the new child would be welcomed as a blessed addition to the family. Similarly, the parents might argue that not availing themselves of cloning violates their duty to care for their ailing child.

A ban on cloning does raise interesting questions about the moral obligations that surround human reproduction. We could find cloning inherently immoral because parents would use cloning only to satisfy their own selfish, narcissistic, and unreasonable desires. Interestingly, the same claims can be made of ordinary reproduction, yet a ban on traditional procreation hardly seems a popular idea. Comparatively, we could find a ban on human cloning inherently immoral because it deprives many individuals the opportunity to reproduce in a manner that maximizes their well-being and thus correspondingly maximizes the well-being of their children. If protection of reproductive autonomy is a value worthy of moral obligation, then banning cloning would violate our moral duty to assure procreative freedom.

b. Deontology and the Problem of Moral Absolutism

A second criticism of deontology is its assumption about the moral rightness and wrongness of human conduct. Deontologists operate from the premise that there are moral absolutes in the world; certain conduct is morally correct and other actions are morally wrong. ${ }^{121}$ But in our diverse and changing world, a system that depends on moral absoluteness is destined for challenge. Who or what is to be the arbiter of moral rightness? Actions that a large

${ }^{120} I d$. at 61 .

${ }^{121} I d$. at $60-62$. 
group might consider morally wrong an equally large group could view as morally acceptable. A Gallup Poll conducted in March 2002 is a chilling illustration that one person's sin is another person's sanctity. ${ }^{122}$ The poll asked citizens of Kuwait, the country the United States defended in the 1991 Persian Gulf War, if the September 11, 2001 attacks on the World Trade Center could be morally justified. ${ }^{123}$ A full thirty-six percent responded that the perpetrators were morally justified in killing nearly 3000 individuals. ${ }^{124}$ Though the survey was not conducted on U.S. citizens, it seems reasonable to assume that few if any Americans would find moral justification for the September 11 th attacks.

Clearly, morality is a complicated concept. One can assess the morality of a ban on human reproductive cloning according to any of the various ethical theories that comprise the field of moral philosophy. No single theory is necessarily superior to another and each could add a unique analysis to the moral evaluation of human cloning. Thus far, we have considered the ethics of cloning from the perspectives of utilitarianism and deontology. From the standpoint of utility, a balance of the benefits and harms of human cloning does not reveal a clear moral choice. To date, the benefits and harms are largely unknown, thus the weighing of good and bad consequences is purely a matter of speculation. If cloning proves a safe and effective method of reproduction, however, then it seems likely that a utilitarian would approve of the process for the benefits it could provide to numerous individuals.

The benefits of aiding infertile couples, single and gay couples, parents who wish to avoid passing a deleterious gene to a child, and parents seeking solace for the death of a child would probably outweigh the more speculative harms such as the effacement of individuality, the commodification of children, and the advancement of eugenics. These latter two harms have been previously raised in the context of emerging reproductive technologies such as in vitro fertilization, preimplantation genetic diagnosis, and the use of donor gametes, but there is no evidence that these harms have come to pass. The argument that cloning threatens individuality must be assessed under the presumption that each cloned child would be born in the same manner as other children-following gestation by an intended

122 See Dave Moniz, Some Kuwaitis Dispute Anti-U.S. Results, USA TODAY, Mar. 5, 2002, at 11A (reporting on a February 2002 Gallup Poll in which thirty-six percent of Kuwaitis found the terrorist attacks on the World Trade Center "morally justified," while forty-one percent held an unfavorable opinion of the United States).

${ }^{123} I d$.

${ }^{124} I d$. 
mother or gestational carrier-and that the child would experience the world in his or her own unique way. Different historical time frames, different parents, different extended family, and even different uterine environments assure that the cloned individual will not lead the same life as the cell donor. At most, cloning provides a glimpse into the future, but it is far from a magical crystal ball.

A moral assessment of a cloning ban from a deontological perspective is challenging because of the competing and uncertain moral obligations that surround both reproductive technologies and the advancement of science. If it is moral to thwart research efforts that could potentially benefit humankind because of legitimate safety concerns, then deontologists would find human cloning morally unacceptable, at least until safety could be assured and perhaps even thereafter. But if mankind has a moral obligation to advance our understanding of the creation of human life, then we can morally pursue the safest methods of human cloning. Because each individual brings his or her own moral compass to this debate, the morality of a ban on human cloning is not readily apparent.

\section{B. Is a Ban on Human Cloning Legal?}

The groundswell of support for a ban on human reproductive cloning proceeds seemingly unencumbered by concerns about the legality of such a measure. Proponents of a cloning ban speak little, if at all, about the legal or constitutional merits of forestalling scientific inquiry into the workings of human SCNT. The popularity of a ban on reproductive cloning assumes the mantle of legality, if for no other reason than the popular outrage that would follow any decision to the contrary. It may be the case that public support for a ban on reproductive cloning is so strong that any legal challenge to an enacted ban would be summarily dismissed, with no judge willing to be perceived as dooming the human species. ${ }^{125}$

While those in the political arena seem to have confidence in the inevitable legality of cloning bans, other commentators have questioned whether a total ban on this form of human reproduction

\footnotetext{
125 Needless to say, our judicial system is replete with judges who are fully willing and capable of striking down even the most popular measures because they run afoul of existing constitutional principles. Coincidentally, one such decision was handed down as this article was being written. In Newdow v. U.S. Congress, 292 F.3d 597 (9th Cir. 2002), the Ninth Circuit Court of Appeals ruled that a school district's policy requiring teacher-led recitation of the Pledge of Allegiance and a statute inserting the words "under God" into the Pledge violated the Establishment Clause of the First Amendment.
} 
could pass constitutional muster. ${ }^{126}$ The scholars who have weighed in on the question are impressive in both their number and breadth of knowledge in matters of reproductive jurisprudence. ${ }^{127}$ For this reason, this Part will attempt to marshal the prior commentary and analysis on the legal aspects of a cloning ban, ultimately agreeing with those who conclude that neutral application of constitutional jurisprudence supports a finding that a total ban on reproductive cloning is unconstitutional. At the same time, I confess a healthy skepticism that any American court in the foreseeable future would reach the same result.

Having set forth this prediction of discord between merit and result, let us look briefly at two of the major arguments against enforcement of a total ban on reproductive cloning. Please note that other scholars have ably analyzed the legality of cloning bans, often focusing on the several constitutional infirmities that these everpopular statutes display. ${ }^{128} \mathrm{My}$ aim is to present the two strongest arguments against a total ban on human cloning. The challenges discussed herein are as follows: 1) federal and state cloning bans violate procreative liberty by depriving individuals of reproductive choice, and 2) existing cloning bans are unconstitutionally vague because they fail to define explicitly what conduct is unlawful. ${ }^{129}$ Both

126 See Charles Kunich, The Naked Clone, 91 Ky. L.J. 1. 30-61 (2002); see also Robertson, supra note 95, at 1399.

127 See, e.g., Lori B. Andrews, Is There A Right to Clone? Constitutional Challenges To Bans On Human Cloning, 11 HaRv. J.L. \& TeCH. 643 (1998); George J. Annas, Human Cloning: A Choice or an Echo?, 23 U. DAYTON L. REv. 247 (1998); Ronald Chester, To $\mathrm{Be}, \mathrm{Be}, \mathrm{Be}$. . . Not Just to Be: Legal and Social Implications of Cloning for Human Reproduction, 49 FLA. L. REV. 303 (1997); Daniel Mark Cohen, Cloning and the Constitution, Cloning and the Constitution, Cloning and the Constitution, Cloning and . ., 26 Nova L. Rev. 511 (2002); Debra Feuerberg Duffy, To Be or Not to Be: The Legal Ramifications of the Cloning of Human Embryos, 21 RUTGERS COMPUTER \& TECH. L.J. 189 (1995); Elizabeth Price Foley, The Constitutional Implications of Human Cloning, 42 ARIZ. L. REV. 647 (2000); Clarke D. Forsythe, Human Cloning and the Constitution, 32 VAL. U. L. Rev. 469 (1998); Michael I. Kahn, Clowning Around With Clones: The Moral and Legal Implications of Human Cloning, 3 U.S.F. J.L. \& Soc. Challenges 161 (1999); Anne Lawton, The Frankenstein Controversy: The Constitutionality of a Federal Ban on Cloning, 87 Ky. L.J. 277 (1998); Robertson, supra note 95; Susan Tall, Legal and Ethical Implications of Human Procreative Cloning, 3 U.S.F. J.L. \& SOC. CHALlenges 25 (1999).

128 See, e.g., Andrews, supra note 127, at 661-76 (analyzing whether cloning bans are unconstitutionally vague, infringe upon a constitutional right of scientific inquiry, or infringe upon the right to make reproductive decisions); Cohen, supra note 127, at 527-42 (discussing cloning as it relates to reproductive freedom, principles of Equal Protection, and freedom of speech); Foley, supra note 127, at 677709 (discussing cloning bans and the First Amendment right of scientific inquiry, the Due Process Clause procreational liberty interest, and the Equal Protection Clause).

${ }^{129}$ A third challenge that I initially considered viable, but ultimately dismissed, is the assertion that a federal ban on cloning would exceed the federal government's 
of these arguments are worthy of exploration as each proceeds from a well-established body of constitutional jurisprudence. Yet, the unique aspects of cloning will undoubtedly influence the analogies and distinctions to existing practices that traditionally guide our courts' legal reasoning.

\section{Does a Cloning Ban Violate Protected Procreational Liberty?}

A total ban on human reproductive cloning would outlaw a method by which children are conceived, an unprecedented action in American jurisprudence. ${ }^{130}$ Over the past century, our courts have produced a rich and evolving body of law wrestling with cases in which governmental bodies have sought to regulate the conduct surrounding conception, gestation, and childbirth. ${ }^{131}$ On balance, this body of law has displayed deference to each individuals right to make highly personal decisions regarding conception and childbirth. ${ }^{132}$ In the oft-cited quote from Justice Brennan, we are assured that " $[\mathrm{i}] \mathrm{f}$ the right of privacy means anything, it is the right of the individual, married or single, to be free from unwarranted governmental intrusion into matters so fundamentally affecting a person as the decision whether to bear or beget a child." 133 Whether cloning would enjoy the protections of this and other established rights is now unknown, but has been the subject of much academic

authority to regulate the practice of medicine. The argument begins with the assertion that cloning is strictly a medical practice, the regulation of which is traditionally left to individual states. See State of Oregon v. Ashcroft, 192 F. Supp. 2d 1077 (D. Or. 2002). I confess that even this prong of the argument is unlikely to hold up, given the groundswell of repugnance surrounding the technique. Even if cloning is viewed as a medical practice governed by state standards, it seems wellsettled that national enactments may specify and clearly define what is lawful and what is not. Id. at 1092. Moreover, Congress' authority to regulate, and even ban, human reproductive cloning can likely be found in the Commerce Clause, which gives Congress the power to regulate interstate commerce. See U.S. Const. art. I, § 8, cl. 1. As Professor Lori Andrews points out, there are numerous cases suggesting that the activities surrounding cloning would be considered to have a substantial impact on interstate commerce. From the ordering of supplies to the luring of individuals from across state borders, any individual or facility that offered reproductive cloning could hardly remain an intrastate operator. See Andrews, supra note 127, at 670-76.

${ }^{130}$ The introduction of artificial insemination in the 1950 s did bring calls for criminalization of this new technology, but ultimately no prohibitory statutes were enacted. See Daar, supra note 57, at 171 (discussing the history of AID in the United States and abroad).

131 See infra notes 133-53 and accompanying text.

132 Id.

133 Eisenstadt v. Baird, 405 U.S. 438, 453 (1972). 
speculation. ${ }^{134}$

In order to understand the protections accorded the right to procreational autonomy, we must begin with the text of the U.S. Constitution. The Due Process Clauses of the Fifth and Fourteenth Amendments prohibit, respectively, federal or state governments from depriving any individual of "life, liberty, or property without due process of law." ${ }^{\text {"35 }}$ This constitutional language has been interpreted to contain a substantive component, meaning that the government must provide sufficient justification for taking away an individual's life, liberty, or property. ${ }^{136}$ The level of judicial scrutiny accorded the government's proferred justification depends upon the nature of the rights involved. Courts will apply strict scrutiny to evaluate the infringement. ${ }^{137}$ Under a strict scrutiny analysis, the government will satisfy substantive due process only if it can prove that the law is necessary to achieve a compelling state purpose. ${ }^{13}$

The inception of the substantive liberty interest and its protection of the right to procreate can be traced to the 1942 decision in Skinner v. Oklahoma. ${ }^{139}$ In Skinner, the Court invalidated the Oklahoma Habitual Criminal Sterilization Act, which allowed

\footnotetext{
134 See, e.g., Andrews, supra note 127, at 666 (arguing cloning is too qualitatively different from normal reproduction to assume that the same Constitutional protections would apply); Foley, supra note 100, at 700-04 (concluding that cloning is a form of reproduction deserving the same protections as other forms of reproduction); Robertson, supra note 127, at 1391 (arguing that some forms of cloning show aspects of reproduction deserving of procreative liberty protection).

135 U.S. ConsT. amends. V \& XIV, § 1.

136 See Planned Parenthood of Southeastern Pa. v. Casey, 505 U.S. 833, 846 (1992) (stating that the Due Process Clause of the Fourteenth Amendment "has been understood to contain a substantive component as well, one 'barring certain government actions regardless of the fairness of the procedures used to implement them"”).

137 See Skinner v. Oklahoma, 316 U.S. 535, 541 (1942) (holding that " $[\mathrm{m}]$ arriage and procreation are fundamental to the very existence and survival of the race, [thus] strict scrutiny is essential" when examining laws that seek to infringe on these rights).

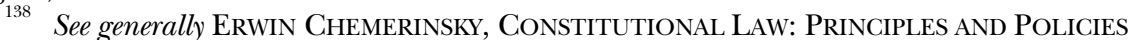
419-20 (1997) (discussing the history and meaning of substantive due process).

139316 U.S. 535 (1942). An earlier case, Meyer v. Nebraska, 262 U.S. 390 (1923) first established that the liberty interest protected by the Constitution encompassed more than the right to be free from physical restraint. The Court stated that the liberty interest of the Due Process Clause "denotes not merely freedom from bodily restraint but also the right of the individual . . . to marry, establish a home and bring up children .... and generally to enjoy those privileges long recognized at common law as essential to the orderly pursuit of happiness by free men." Id. at 399. While Meyer implies a positive right of procreation, it is the later Skinner case that fully establishes the link between the Due Process liberty interest and the right to procreate.
} 
courts to order the sterilization of individuals convicted two or more times for felonies involving "moral turpitude." 140 Writing for the Court, Justice Douglas described the right to have offspring as "one of the basic civil rights of man."141 "Marriage and procreation," one Justice explained, "are fundamental to the very existence and survival of the race." ${ }^{142}$ One who is deprived by the state of the right to reproduce "is forever deprived of a basic liberty." ${ }^{143}$ The holding and language in the decision indicate the Court's designation of procreation as a fundamental right, deserving of protection against governmental restriction unless compelling reasons for interference can be shown. ${ }^{144}$

Following Skinner, the jurisprudence surrounding procreation largely focused on state interference with the individual's right to avoid procreation, either through the use of contraceptives, ${ }^{145}$ or by access to abortion. ${ }^{146}$ Though the cases addressed the specific rights of individuals to avoid procreation, the Supreme Court often spoke more broadly about the protections accorded reproduction as a positive right in our society. ${ }^{147}$ As noted above, in Eisenstadt $v$. Baird, a case invalidating a law prohibiting distribution of contraceptives to unmarried individuals, Justice Brennan reminded us of the importance of procreation. Writing for the Court, Justice Brennan spoke of the decision whether "to bear or beget a child" as a

${ }^{140}$ Skinner, 316 U.S. at 536.

141 Id. at 541 .

${ }^{142} I d$.

143 Id.

144 The Court in Skinner based its holding on the Equal Protection Clause, finding that the Oklahoma law forced sterilization upon certain habitual felons convicted of crimes of moral turpitude, while other habitual felons were untouched by the law. But the broad language regarding the right to procreate has been interpreted to mean that the liberty interest protected by the Due Process Clause includes the right "to have children." See Washington v. Glucksberg, 521 U.S. 702, 720 (1997) (citing Skinner, 316 U.S. at 535).

${ }^{145}$ See, e.g., Griswold v. Connecticut, 381 U.S. $479 \quad$ (1965) (declaring unconstitutional a state law prohibiting the use and distribution of contraceptives); Eisenstadt v. Baird, 405 U.S. 438 (1972) (invalidating a Massachusetts law that prohibited distribution of contraceptives to unmarried individuals); Carey v. Population Servs. Int'l, 431 U.S. 678 (1977) (holding unconstitutional a New York law that made it a crime to sell or distribute contraceptives to minors under sixteen years of age).

${ }^{146}$ See, e.g., Roe v. Wade, 410 U.S. 113 (1973) (declaring that the Constitution protects a woman's right to choose to terminate her pregnancy prior to fetal viability); Casey, 505 U.S. at 846 (reaffirming the essential holding in Roe that the government may not ban abortions before viability, but may regulate abortion so long as it does not place an "undue burden" on access to abortions).

${ }^{147}$ See Skinner, 316 U.S. at 541. 
protected right under the constitutional right to privacy. ${ }^{148}$ A quarter century later, the Court reiterated its view that procreation is a fundamental right. In Washington v. Glucksberg, the Court cited Skinner for the proposition that the "liberty" interest protected by the Due Process Clause includes the right "to have children." ${ }^{149}$ Thus, whether grounded in a right of privacy or the liberty interest expressly contained in the Constitution, the idea is widely accepted that traditional coital reproduction is protected against governmental interference unless the state can show compelling reasons for imposing restrictions..$^{150}$

It is essential to consider that the above-described body of law dealing with procreational liberty and reproductive choice has arisen in the context of traditional conception through sexual intercourse. Whether these principles can be applied to noncoital forms of reproduction, including cloning, is the subject of intense debate and discussion. For several years now, commentators have waxed eloquent about the applicability of a long-established procreative rights jurisprudence to newly emerging reproductive technologies that were virtually unknown when the relevant legal principles were being developed. In the case of reproductive cloning, powerful arguments have been made both advocating and decrying the application of traditional, protective principles to this controversial form of reproduction. ${ }^{151}$

On the one hand, some argue that cloning is a form of reproduction deserving of constitutional protection equal to that accorded other methods of childbearing. ${ }^{152}$ This argument assumes, of course, that other forms of non-traditional reproduction, such as in vitro fertilization and artificial insemination, receive the same substantive due process protections accorded coital reproduction. To date, courts have discussed this issue minimally, but there are scattered indications that courts would view certain forms of assisted reproduction on equal footing with traditional reproduction. ${ }^{153}$

148 California v. Byers, 402 U.S. 424, 453 (1971).

149 Glucksberg, 521 U.S. at 720 (citing Skinner, 316 U.S. at 535).

${ }^{150}$ For a general discussion of the moral and legal arguments for procreative liberty, see John A. Robertson, Children of Choice: Freedom and the New ReProductive TECHNOLOGIES 22-42 (1994).

151 See supra note 134.

152 Robertson, supra note 95, at 1389-1403.

153 The most direct indication of such parity can be found in Lifchez $v$. Hartigan, 735 F. Supp. 1361 (N.D. Ill.), aff'd mem., 914 F.2d 260 (7th Cir. 1990), in which the district court held that the right to make procreative decisions encompasses the right of an infertile couple to undergo medically-assisted reproduction, including in vitro fertilization and the use of a donated embryo. In plain and direct language, the 
Professor John Robertson has written extensively about the moral and legal underpinnings for including certain forms of assisted reproduction within the bounds of procreative liberty. ${ }^{154}$ In the case of cloning, he argues that if current forms of assisted reproduction fall within prevailing notions of procreative freedom, "then a strong argument exists that some forms of cloning share certain aspects of procreative liberty as well, for cloning shares many features with assisted reproduction and genetic selection." 155

Under Robertson's view, the forms of cloning that should be accorded procreative liberty protections are those in which an individual has a gestational or biological relationship to the cloned child, coupled with an intent to rear that child. ${ }^{156}$ In the normal course, constitutional protections have vested in those who either bear (gestate) ${ }^{157}$-or beget (produce) ${ }^{158}$ - a child, that is, to those who are traditionally considered the mother and father of the child. In the case of cloning, the "bearer" would be the gestational carrier of the cloned embryo and the "begetter" would be the DNA donor. ${ }^{159}$ Essentially, Robertson makes the argument that these individuals would not necessarily be entitled to constitutional protection if they lacked the intent to rear the resulting child. ${ }^{160}$ He argues, "[a]ny right to clone by persons who do not intend to rear would have to derive from the right of those who end up rearing." ${ }^{161}$ The reason for this somewhat restrictive view, Robertson explains, is to anticipate and squarely address the oft-expressed concern that cloning will disaggregate the reproductive and rearing processes, leaving children the victims of adult grandiosity and ambition. ${ }^{162}$ According procreative liberty protection to those who engage in cloning without the intent to rear, Robertson warns, "seems to treat children like

court explained, "It takes no great leap of logic to see that within the cluster of constitutionally protected choices that includes the right to have access to contraceptives, there must be included within that cluster the right to submit to a medical procedure that may bring about, rather than prevent, pregnancy." Id. at 1377.

154 See Robertson, supra note 95.

155 Id. at 1391. The most notable similarities include the enabling of married couples to have healthy, biologically related children for rearing, or allowing a couple to obtain a source of tissue for transplant to an ailing child. Id.

${ }^{156} I d$. at 1395-1404.

157 Bear is defined as "to give birth to.” Merriam-Webster Dictionary 75 (1974).

${ }^{158}$ Beget is defined as "to become the father of." Id. at 77.

159 For a fuller discussion of the constitutional protections afforded gestational and biological parents, see Foley, supra note 127, at 700-02 (2000).

${ }^{160} I d$. at $1398-99$.

161 Robertson, supra note 95, at 1399.

162 Id. 
fungible commodities produced for profit without regard to their well-being. It should not be deemed part of the initiating couple's procreative liberty."

Professor Elizabeth Price Foley expresses a broader view of the parity between cloning and other assisted reproductive technologies. Simply put, Foley posits that "[b]ecause cloning is merely an asexual form of procreation, it is arguably as much a fundamental constitutional right as our right to procreate by either passion or the petri dish." ${ }^{164}$ In a recent article, Foley critiques Robertson's view that procreational liberty should lie only where the gestational or biological actors possess an intent to rear the resulting child. ${ }^{165}$ Foley draws an analogy to traditional adoption scenarios where the pregnant woman and biological father agree to surrender the child upon birth. ${ }^{166}$ Such a decision would not then terminate the procreational liberty of either the gestating "bearer" or the genetically-related "begetter." 167 For example, if the woman chose to terminate her pregnancy, she could exercise that reproductive liberty within the bounds of prevailing state law. Foley argues that just as intent is irrelevant to the application of reproductive freedoms in coital conception, neither should it play a role in according rights when cloning techniques are used to conceive a child. ${ }^{168}$ In poignant language, she argues that "unless we are prepared to institute "mind police' to enforce the appropriate moral or ethical standards for conceiving a child, there is no place in the law of procreational liberty for distinctions based upon the often inchoate and questionable motivations of parents." ${ }^{, 19}$ The view that cloning is simply an additional reproductive option in our growing arsenal of assisted technologies is linked logically with the assertion that a ban on cloning is a deprivation of reproductive liberty. ${ }^{170}$ Yet even this

${ }^{163} I d$.

164 Foley, supra note 127, at 695.

165 Id. at 702.

166 Id. at 702-03.

167 Id. at 703 .

168 Id.

169 Id. at 704 .

170 A finding that a cloning ban is a deprivation of reproductive liberties would not automatically invalidate such a law. Instead, the court would use strict scrutiny to evaluate whether the government has a sufficiently compelling interest in stopping the practice. As Professor Erwin Chemerinsky explains, " $[\mathrm{u}]$ nder strict scrutiny, a law will be upheld if it is necessary to achieve a compelling government purpose. In other words, the court must regard the government's purpose as vital, as 'compelling.' Also, the law must be shown to be 'necessary' as a means to accomplishing the end. This requires proof that the law is the least restrictive or least discriminatory alternative." CHEMERINSKY, supra note 138, at 416 (emphasis in original; citations omitted). When 
foundational point, that cloning is a form of reproduction, is highly disputed. A prominent voice among those who find cloning distinguishable from other ARTs is Professor Lori Andrews. She argues that "cloning is too qualitatively different from normal reproduction and from the types of assisted reproduction protected by the . . . case [law] to simply assume that the same Constitutional protections apply." Cloning, she argues, "is not a process of genetic mix, but of genetic duplication," which is sufficiently different from reproduction in which a unique genotype is formed. ${ }^{172}$ George Annas joins Andrews in her views and warns that " $[t]$ his change in kind in the fundamental way in which humans can 'reproduce' represents such a challenge to human dignity and the potential devaluation of human life ... that even the search for an analogy has come up empty handed."173

Proponents of a ban on reproductive cloning will likely respond to a constitutional challenge based on procreative liberty with the assertion that cloning is distinguishable from other forms of reproduction sufficient to justify its exclusion from the protected realm of conduct that constitutes our reproductive freedom. Those distinguishing characteristics might include the fact that cloning is an asexual form of reproduction, meaning that it does not require the sexual union of sperm and egg to begin the process of cell division. ${ }^{174}$ All other known forms of reproduction, including currently employed ARTs, such as artificial insemination and in vitro fertilization, are forms of sexual reproduction because they rely on the joining of the egg and sperm. ${ }^{175}$ Cloning may be further distinguished because it results in a child whose genotype matches that of an existing person. Other forms of reproduction result in a

strict scrutiny is applied, laws are generally declared unconstitutional. Id. Whether a cloning ban would warrant and then survive strict scrutiny remains to be seen, but at least one scholar speculates on the various state interests that would be raised in a cloning ban challenge. See Foley, supra note 127, at 709-30 (including the preservation of the traditional family, the protection of personal autonomy and privacy, the preservation of the sanctity of human life, the protection of the health and safety of human embryos, and the preservation of human genetic diversity).

${ }^{171}$ Andrews, supra note 127, at 666.

172 Id.

173 Scientific Discoveries in Cloning: Challenges for Public Policy: Hearing Before the Subcomm. On Public Health and Safety of the Senate Comm. On Labor and Human Resources, 105th Cong. 44 (1997) (statement of George Annas), as cited in Andrews, supra note 127 , at 666.

${ }^{174}$ See Thomas W. Hilgers, The New Technologies of Birth and Death, in THE New Technologies of Birth and Death: Medical, Legal and Moral Dimensions 29, 46 47 (1980).

${ }^{175}$ See Foley, supra note 127, at 652 n.29. 
mixed, unique genotype. Perhaps cloning will be separated out because it is the only known form of reproduction that does not require the involvement of a male. Perhaps for these and other reasons, those who would exclude cloning from the ambit of protected reproductive freedoms are making an implicit assertion that the "differentness" of cloning is normatively a negative quality.

I have previously observed that the initial overwhelmingly negative reactions to cloning are reminiscent of furors that encircled prior advances in reproductive medicine. ${ }^{176}$ Two modalities in particular, artificial insemination by donor (AID) and in vitro fertilization (IVF), faced intense public skepticism and anxiety when first introduced. Like their successor cloning technology, AID and IVF stirred up dire warnings about the victimization of children and the doomed fate of mankind should such unnatural methods of reproduction be embraced. ${ }^{177}$ When AID was introduced in the $1950 \mathrm{~s},{ }^{178}$ critics called it "nothing more than mechanical adultery" injurious to the essential nature and structure of the family. ${ }^{179}$ The introduction of IVF in the 1970s was likewise condemned as immoral, with one scholar proposing that "technological reproduction" should never be used to supplant human procreation. ${ }^{180}$ Today both methods of noncoital reproduction enjoy considerable favor, combining to account for the birth of over 60,000 children annually. ${ }^{18}$

Whether cloning will achieve the technical and social successes now enjoyed by once-condemned reproductive technologies remains to be seen, but one similarity is already apparent. Cloning is, at its very core, a method of human reproduction. To reproduce, or

176 See Daar, supra note 57, at 171.

177 See id. at 169-82.

178 The history of AID, which actually dates back to the late $1800 \mathrm{~s}$, is described in Daar, supra note 57, at 169-70.

${ }^{179}$ See Alberty R. Jonsen, Reproduction and Rationality, 4 CAMBridge Q. HEALTHCARE ETHICS 263 (1995).

180 See Paul Ramsey, Shall We Reproduce"?, 220 JAMA 1346 (1972).

181 See Machelle M. Seibel, Therapeutic Donor Insemination, in FAmily BuILDING Through EgG AND Sperm Donation 34 (Machelle M. Seibel \& Susan L. Crockin eds.,1996) (reporting AID accounts for nearly 30,000 births annually); see also Society for Assisted Reproductive Technology and the American Society for Reproductive Medicine, Assisted Reproductive Technology in the United States: 1998 Results Generated From the American Society for Reproductive Medicine/ Society for Assisted Reproductive Technology Registry, 77 FERTILITY \& STERILITY 18 (2002) (reporting the birth of 29,128 neonates through the use of IVF and other similar reproductive technologies). In fact, the number of children born worldwide through IVF is much higher because the ASRM statistics only include clinics in the United States. 
"produce again or anew"182 is, and will remain, a mystery of the human condition, with the vast majority opting for the method of least resistance. Common sense dictates that the leading choice for reproduction will be the old-fashioned way, followed in turn by methods that involve the least time, money, and effort. Cloning may soon join the rank of available reproductive technologies, but it will be a rare couple or individual who opts for what will undoubtedly be a highly expensive, initially highly experimental treatment. Cloning will serve as a treatment of last resort when all other therapies have failed or cannot guard against heritable genetic defects. And for those individuals who turn to cloning to replace a lost child, let us remember that in the end, cloning produces a child. One's capacity to love and cherish that child will be no more affected by genotype than it is by the many other qualities that the child brings to life.

From a procreative liberty perspective, once cloning is proven safe and effective, there seems to be no compelling reason to exclude this process from the ranks of other forms of protected reproductive activities. Couples and individuals who seek out cloning will be a rare breed, many of whom will have suffered the pain of intractable infertility or worse, the loss of a child. To deny these individuals, or even individuals who choose to reproduce through cloning for reasons that appear idiosyncratic but are deeply rooted, can only serve to empower the government to make lifestyle choices for society that today seem beyond the realm of contemplation. Deprivation of the right to reproduce in a manner one chooses strikes at the heart of the liberty interest.

\section{Is a Total Ban On Human Cloning Unconstitutionally Vague?}

A federal or state statute that bans human cloning may be subject to challenge as unconstitutionally vague. A law that is vague, especially but not exclusively a criminal law, violates the Due Process Clause of the Fourteenth Amendment in three ways. First, a vague law fails to give adequate notice of prohibited conduct. ${ }^{183}$ Without such notice, it is impossible for individuals to regulate their conduct within legal bounds. ${ }^{184}$ Courts often summarize this prong of the

\footnotetext{
182 "Reproduce" is defined as "to produce again anew . . . or . . . to bear offspring." WEBSTER's NEW WORLD DicTIONARY 1140 (1986).

${ }_{183}$ Lifchez v. Hartigan, 735 F. Supp. 1361, 1364 (N.D. Ill. 1990), aff'd mem., 914 F.2d 260 (7th Cir. 1990) (citing Smith v. Goguen, 415 U.S. 566, 572 n.8 (1974)).

${ }^{184} I d$. Due Process guarantees individuals the right to fair notice of whether their conduct is prohibited by law. Colautti v. Franklin, 439 U.S. 379, 390-91, 399 (1979) (citing United States v. Harriss, 347 U.S. 612, 617 (1954)). Although only
} 
vagueness standard by admonishing that "a statute is void for vagueness if persons of 'common intelligence must necessarily guess at its meaning." 185 Second, vague statutes invite arbitrary and discriminatory enforcement by police, judges, and juries. Because a vague law fails to define explicitly what conduct is unlawful, its enforcers and interpreters may pursue their personal predilections in finding a violation, rather than adhering to an objective standard. ${ }^{186}$ Third, vague standards of unlawful conduct inevitably cause people to overestimate the range of prohibited conduct, thus inhibiting lawful, and even constitutionally protected, conduct. ${ }^{187}$

A statutory ban on cloning may be challenged as impermissibly vague by those individuals whose conduct would be affected or proscribed by the statute. Potential plaintiffs might include researchers, physicians, or even patients who may fall within the parameters of the statutory language. ${ }^{188}$ A court's review of any vagueness challenge will inevitably require close review of the statutory language, and in some instances may include reference to the legislative history surrounding the enactment. ${ }^{189}$ A law which imposes civil penalties for the proscribed conduct may be found unconstitutionally vague. ${ }^{190} \quad$ In the case of a criminal statute, vagueness review is even more exacting than in the civil context. ${ }^{191}$

constructive rather than actual notice is required, individuals must be given a reasonable opportunity to discern whether their conduct is proscribed so they can choose whether or not to comply with the law. Forbes v. Napolitano, 236 F.3d 1009, 1011 (9th Cir. 2000) (citing Giaccio v. Pennsylvania, 382 U.S. 399, $402-03$ (1966)).

185 Planned Parenthood v. Arizona, 718 F.2d 938, 947 (9th Cir. 1983).

186 Id. (citing Smith v. Goguen, 415 U.S. 566, 575 (1974) (commenting that statutory language of "standardless sweep allows policemen, prosecutors, and juries to pursue their personal predilections. Legislatures may not so abdicate their responsibilities for setting the standard of the criminal law")).

${ }^{187}$ Id. (citing Colautti, 439 U.S. at 391) (holding unconstitutionally vague an abortion law requiring persons performing abortions to preserve life of fetus if it could be determined that the fetus "is viable or if there is sufficient reason to believe that the fetus may be viable ....").

${ }^{188}$ For example, in Forbes $v$. Napolitano, 236 F.3d 1009 (9th Cir. 2000) plaintiff patients challenged an Arizona abortion law which they contended preventing them from obtaining fetal tissue transplantation, considered by some a life-saving medical treatment for Parkinson's Disease.

189 See, e.g., Lifchez v. Hartigan, 735 F. Supp. 1361, 1369 (N.D. Ill. 1990) (quoting extensively from the legislative history surrounding the Illinois Abortion Law in a vagueness challenge by a class of physicians).

${ }_{190}$ For example, in Village of Hoffman Estates v. Flipside, Hoffman Estates, Inc., the Court analyized a law that imposed only a fine between $\$ 10$ and $\$ 500$. 455 U.S. 489, 492. The Court, however, determined that this law survived a challenge because it did not unreasonably limit protected conduct. Id. at 495.

${ }^{191}$ See Kolender v. Lawson, 461 U.S. 352, 357 (1983) (holding that penal statutes must define criminal offenses with "sufficient definiteness," and "in a manner that 
To date, seven states have enacted statutory cloning bans, including: Arkansas, ${ }^{192}$ California, ${ }^{193}$ Louisiana, ${ }^{194}$ Michigan, ${ }^{195}$ Missouri, ${ }^{196}$ Rhode Island, ${ }^{197}$ and Virginia. ${ }^{198}$ All six statutes provide civil penalties for engaging in human cloning, ranging in severity from $\$ 50,000$ "for each incident," 199 to $\$ 10,000,000$ for any attempt to engage in human cloning. ${ }^{200}$ In addition, the state of Louisiana imposes criminal penalties on any person who "clone[s] or attempt[s] to clone a human being. ${ }^{201}$ The crime of cloning in Louisiana is punishable by civil fine of not more than ten million dollars; imprisonment, for not more than ten years; or both. ${ }^{202}$ Because Louisiana is the only state currently imposing criminal penalties for cloning activities, it may be instructive to evaluate the viability of a vagueness challenge to Louisiana's cloning ban. ${ }^{203}$

As a threshold inquiry, a wide range of plaintiffs may have standing to challenge Louisiana's cloning ban on vagueness grounds. The statute provides that " $[\mathrm{n}]$ o person shall clone or attempt to clone a human being." 204 Under the statute, a "person" include a researcher who develops a cloning technique, a physician who employs such technique on behalf of a patient, and even the patient who consents to participate in the cloning activities by providing the somatic cell to be used for transfer. A person who initiates the cloning process by enlisting the services of one or more skilled clonists may under the broad statutory language have attempted to clone a human being. Read liberally, an "attempt" under the statute may not require the medical know-how to actually achieve the desired

\footnotetext{
does not encourage arbitrary and discriminatory enforcement"); Winters v. New York, 333 U.S. 507, 515 (1948) (holding that where a statute imposes criminal penalties, the standard of certainty involved in vagueness review is higher).

${ }^{192}$ S. 185, 2003 Reg. Sess. (Ark. 2003).

193 Cal. Health \& SAFETy Code $\$ 24185$ (West 2002).

194 LA. REv. STAT. ANN. § 1299.36.2 (West 2002).

195 Mich. Comp. LaWs ANN. $§ 333.16274$ (West 2002).

196 Mo. AnN. STAT. $\$ 1.217$ (West 2002) (providing that "no state funds shall be used for research with respect to the cloning of a human person").

197 R.I. GEN. LAWS $\$$ 23-16.4-1 (2002).

198 VA. Code ANN. \$ 32.1-162.22 (2002).

199 Id. at $\$ 32.1-162.22(\mathrm{C})$.

200 Mich. Comp. Laws ANN. \$ 333.16275(3) (West 2002); see also LA. Rev. STAT. ANN. § 1299.36.2(D) (West 2002).

${ }_{201}$ LA. ReV. STAT. ANN. $\$ 1299.36 .2$ (D) (West 2002).

${ }^{202} I d$.

203 The newly enacted Arkansas statute, which was signed into law on March 24, 2003, makes human cloning a crime, but does note enumerate any specific criminal penalties.

${ }^{204} I d$. at $§ 1299.36 .2(\mathrm{~A})$.
} 
results, but simply the intent to bring about the birth of a child via cloning.

The terms used to describe the prohibited conduct may also present a vagueness concern. The relevant portions of the law provide:

A. No person shall clone or attempt to clone a human being.

B. No person shall purchase or sell an ovum, zygote, embryo, or fetus with the intent to clone a human being.

C. This Section does not prohibit scientific research or a cell based therapy not specifically prohibited elsewhere by this Part. ${ }^{205}$

The definition of cloning set forth in the statute also raises further vagueness questions:

As used in this Part, "clone" means the practice of creating or attempting to create a human being by transferring the nucleus from a human cell from whatever source into a human egg cell from which the nucleus has been removed for the purpose of or to implant the resulting product to initiate a pregnancy that could result in the birth of a human being. ${ }^{206}$

Read together, these sections of the Louisiana cloning ban are arguably both underinclusive and overinclusive in their descriptions of prohibited conduct, thus leaving "persons of common intelligence .. f forced to guess as to whether or not their conduct is unlawful."207

The described conduct is underinclusive because it does not encompass all of the methods through which human cloning may be achieved. The statute defines cloning as "transferring the nucleus from a human cell . . . into a human egg from which the nucleus has been removed ...." 208 Two scenarios currently under development would clearly fall outside of this definition. First, researchers have achieved promising results using cow eggs as hosts for human DNA. ${ }^{209}$ A researcher who transfers the nucleus from a human cell into a cow egg cell in this manner would not be guilty under the statute, even though her intent would be to create a child using SCNT. Second, researchers in China have been experimenting with a technique that adds the somatic cell nucleus into an egg from which the nucleus has not been removed. Preliminary results show that removing the original nucleus after the somatic cell nucleus has been inserted is a

$205 \quad I d$. at $\$ 1299.36 .2$.

$206 I d$. at $\$ 1299.36 .1$.

${ }^{207}$ Lifchez, 735 F. Supp. at 1364 (N.D. Ill. 1990).

208 LA. REv. STAT. ANN. § 1299.36.1 (West 2002).

209 See Korean Scientists Clone Human Embryo Using Cow Eggs, THE KorEAn HeRALD, Mar. 9, 2002. 
superior technique that improves the early embryo's chance of survival. $^{210}$ Under the strict construction required of a criminal statute, researchers adopting the Chinese method of cloning may reasonably believe that their conduct is not unlawful because the law prohibits only the transfer of a nucleus to an enucleated cell. Although a survey of Louisiana legislators might reveal that the law was intended to cover the Chinese method, the effect of the statute's underinclusive language cannot be denied. ${ }^{211}$

Perhaps a graver infirmity of the Louisiana cloning ban is its potential to inhibit lawful conduct by failing to define clearly "scientific research or a cell based therapy," activities which are exempt under the act. The failure to define a referenced activity, even one that is specifically exempt from prosecution, often renders a statute overbroad and thus impermissibly vague. ${ }^{212}$ For example, in Forbes $v$. Napolitano, ${ }^{213}$ plaintiffs challenged the constitutionality of an Arizona statute that criminalized any medical "experimentation" or "investigation" involving fetal tissue from induced abortions, unless necessary to perform a "routine pathological examination" or to diagnose a maternal or fetal condition that prompted the abortion. ${ }^{214}$ The plaintiffs in Forbes included physicians who wished to provide fetal tissue transplantation to patients suffering from Parkinson's Disease. ${ }^{215}$ The court reviewed the language in the statute, noting the dearth of definitions of key terms, including "experimentation,"

\footnotetext{
210 See Karby Leggett \& Antonio Regalado, As West Mulls Ethics, China Forges Ahead In Stem-Cell Research, WALl ST. J., Mar. 6, 2002, at A1.

${ }^{211}$ Louisiana is not the only state to draft an underinclusive cloning ban. The California statute also defines cloning as the transfer of a nucleus from a human cell "into a human egg from which the nucleus has been removed." Cal. Health \& SAFETY CODE $\$ 24185$ (c) (West 2002). Michigan and Rhode Island use similar language to define cloning. Mich. Comp. Laws ANN. § 333.16274(d) (West 2002); R.I. GEN. LAWS § 23-16.4-2(b) (4) (2002). The Virginia statute creates some ambiguity as the whether removing the original nucleus after the somatic cell nucleus is transfered would be covered. In Virginia, cloning is defined the same as it is in Louisiana and California, but the statute also includes a definition of "somatic cell nuclear transfer" as "transferring the nucleus of a somatic cell of an existing or deceased human into an oocyte from which the chromosomes are removed or rendered inert." VA. CoDE ANN. § 32.1-162.21. Using "are removed" may leave open the possibility that the original chromosomes could be removed after the nucleus is transferred. The broadest definition is provided by Missouri which defines cloning as "the replication of a human person by taking a cell with genetic material and cultivating such cell through the egg, embryo, fetal and newborn stages of development into a new human person.” Mo. AnN. STAT. § 1.217.

212 See Lifchez, 735 F. Supp. at 1364.

213236 F.3d 1009 (9th Cir. 2000).

$214 I d$. at 1010 (citing ARIZ. REV. STAT. § 36-2303).

215 Id.
} 
"investigation," and "routine," and concluded that the statute was unconstitutionally vague because it provided no guidance to physicians as to what conduct would be prohibited and what would be exempt. ${ }^{216}$ Without defining its terms, the statute exempted "routine examination" of fetal tissue, while prohibiting "experimentation" thereon, thus giving doctors inadequate notice as to what conduct would be actionable. ${ }^{217}$ A doctor may undertake a procedure that she views as routine, but the state might consider such a procedure illegal under the statute. Likewise, a physician may refrain from undertaking a particular procedure for fear that he will be arrested for engaging in experimentation. Statutes drafted in this manner are, thus, under- and overinclusive and therefore unconstitutionally vague.

Though the cloning statutes in general, and the Louisiana statute in particular, are careful to define the key term of "cloning," several statutes are remiss in providing a definition of "scientific research." In addition to Louisiana, Michigan, ${ }^{218}$ and Virginia ${ }^{219}$ also explicitly exempt scientific research but provide little guidance as to what such conduct entails. ${ }^{220}$ One concern about the exemption of scientific research is that scientists may be inhibited from pursuing cell-based experimentation for fear of prosecution or imposition of civil fines. The exemption of "research" from the cloning bans is designed to allow and perhaps even encourage therapeutic cloning, a technique that does not result in the birth of a human being. In fact, however, these statutes may have the effect of inhibiting rather than encouraging the study of therapeutic cloning.

For example, if a researcher studies therapeutic cloning and discovers that the cloned embryo produces viable stem cells only after it is implanted in a woman's uterus for some time period and then removed, this form of scientific research would be prohibited in Louisiana because such implantation "could result in the birth of a human being." While a researcher's intent would not be the birth of

${ }^{216} I d$. at $1012-13$.

217 Id. at 1013.

218 Mich. COMP. LAWS ANN. § 333.16274(2) (2002).

219 VA. CODE ANN. § 32.1-162.22(B) (exempting biomedical and agricultural research or practices)

${ }^{220}$ For example, the first part of Michigan's ban reads: "A licensee or registrant shall not engage in or attempt to engage in human cloning." MiCH. COMP. LAwS ANN. § 333.16274(1). The exemption in the second part reads: "Subsection (1) does not prohibit scientific research or cell-based therapies not specifically prohibited by that subsection." Id. at $\S 333.16274(2)$. Part one does not specifically ban any research conduct, but to assume that researchers are free to experiment on cloning would defeat the purpose of the statute. 
a child, the relevant conduct could subject the individual to prosecution because the statute does not explicate a scienter requirement. This suggests an anomalous result: conduct alone, regardless of intent, could subject researchers to criminal liability. Consequently, this would likely chill research that is explicitly exempted by the statute.

A similar infirmity befell the Illinois abortion law in Lifchez $v$. Hartigan. $^{221}$ The statute provided in relevant part, " $[\mathrm{n}]$ o person shall sell or experiment upon a fetus produced by the fertilization of a human ovum by a human sperm unless such experimentation is therapeutic to the fetus thereby produced.... Nothing in subsection (7) is intended to prohibit the performance of in vitro fertilization.,"222 Physicians practicing in the area of reproductive medicine challenged the law as unconstitutionally vague because it failed to define key terms such as "experimentation" and "therapeutic."223 One of the plaintiffs, Dr. Lifchez, argued that the absence of clear guidance from the legislature as to the meaning of these significant terms left him uncertain about the lawfulness of his work using IVF. ${ }^{24}$ Even though the statute exempts "the performance of in vitro fertilization," there are several related techniques, such as embryo transfer and genetic screening of IVF-derived embryos, that are not explicitly exempt under the statute and might have subjected Dr. Lifchez and others to liability. ${ }^{225}$ Moreover, Dr. Lifchez worried that if he tried to improve upon current IVF techniques, even these subtle changes would be undertaken "at his peril.,"226 Any variation of the IVF technique may be therapeutic to the woman trying to conceive, but it is decidedly non-therapeutic to embryos that might be lost in the initial stages of experimentation. Thus, even though the statute exempted IVF from prosecution, it left uncertainty as to how the technique could be undertaken.

221735 F. Supp. 1361 (N.D. Ill. 1990), aff'd mem., 914 F.2d 260 (7th Cir. 1990).

222 ILl. COMP. STAT. \$ 6(7) (1989).

${ }^{223}$ Lifchez, 735 F. Supp. at 1363-64.

224 Id. at $1368-70$.

225 Lifchez, 735 F. Supp. at 1367-69. Specifically, Dr. Lifchez argued and the court agreed that IVF-related procedures such as embryo transfer from one woman's uterus into another woman's uterus, and genetic testing of early embryos accomplished by removing one cell from the eight-celled embryo, might be considered "therapeutic for the woman trying to get pregnant and unnecessarily risky for the developing embryo." Id. at 1368. If these procedures are seen as nontherapeutic to the embryo they could subject physicians to criminal liability even though they "could fall within the statute's in vitro exception." Id. (emphasis in original).

${ }^{226} I d$. at 1369. 
The Lifchez court agreed that the failure to define key terms rendered the statute impermissibly vague because it subjected physicians to uncertainty and possible criminal liability for engaging in seemingly protected conduct. ${ }^{227}$ As noted above, experimentation with therapeutic cloning may obtain a similar result. The exemption for "scientific research or cell-based therapies" in several states" cloning bans may present vagueness problems because the statutes fail to explain the meaning of any of these key terms. Researchers who clone embryos for the purpose of scientific inquiry may find their futures uncertain if their conduct appears to creep toward reproduction, even if their intent lies firmly in purely therapeutic territory. This uncertainty has traditionally formed the basis for declaring a law unconstitutionally vague and no compelling reason emerges to deny cloning bans equal treatment under the law.

Although the current state bans on human cloning seem ripe for constitutional challenge, the chances that such challenges will be upheld are admittedly slim. As to procreative liberty arguments, courts are likely to find that cloning is not within the realm of protected reproductive activities. Even if courts are willing to reach that far, there are sufficiently compelling state interests in banning the practice, at least until such time as issues of safety and efficacy are satisfactorily resolved. As to vagueness concerns, courts may find little or no ambiguity in the prohibitory language, particularly when the statutes impose civil rather than criminal penalties. Thus, with enacted cloning bans predicted to survive and grow in number, it is unlikely that human cloning will not make its way to the shores of our nation. The following section assesses the practical aspects of banning a technology that is snowballing its way into the hearts and minds of scientists worldwide.

\section{Is a Ban on Human Cloning Practical?}

Human cloning as a practical matter is probably best described as a "genie out of the bottle" problem. Human curiosity will continue to pursue a deeper understanding of human biology and scientists will continue to seek mastery over human processes that at one time seemed exclusively within nature's domain. We need only reflect on advances in the artificial heart, the field of organ transplantation and, of course, the burgeoning world of ARTs to see that science continues to overcome nature's barriers in the name of human longevity and well-being. Cloning stirs those same intellectual

${ }^{227} I d$. at 1376 . 
curiosities, and in fact has done so for much of the last century. Experimentation in the field of animal cloning dates back to the 1930 s, when researchers attempted to clone a vertebrate. ${ }^{228}$ Cloning efforts in the 1950s and 1960s focused on amphibia, and attempts at cloning mammals began in the late 1970s. ${ }^{229}$ For cloning researchers, the announcement of Dolly's birth was less a surprise than a confirmation that their collective efforts had yielded a tentative answer-mammalian cloning is possible.

With this natural and long-standing inquiry into cloning, will a ban stop all current and future attempts to clone a human being? If not, what are the implications of enacting statewide, national, or even global cloning bans? Bans on cloning can and do take a variety of forms, from bans on any attempt to create a human embryo using SCNT regardless of the intended use of such an embryo, ${ }^{230}$ to bans on governmental funding of efforts to clone a human being. ${ }^{231}$ The practical effect of any additional ban may be minimal, as research efforts are currently unfunded by the government and numerous jurisdictions have stringent cloning bans in place. Yet we are keenly aware that cloning research and experimentation is underway. To understand this defiant conduct, it is useful to review the various achievements that undergird the human cloning efforts.

\section{Successes and Failures in Animal Cloning}

It may be that Dolly was the first mammal successfully conceived through cloning, but she is no longer alone in her class. Recent reports indicate that scientists have succeeded in cloning rabbits, cattle, goats, mice, pigs, and cats, bringing the current total to seven animal species. ${ }^{232}$ Progress in the cloning of multiple animal species may seem a logical and necessary step in the march toward human cloning, but the results and reactions to animal cloning have stirred rather than quelled concerns over the prospect of human cloning. In the six years since the announcement of Dolly's birth, reports on the safety and efficacy of animal cloning have ranged from "the health of clones is no different than non-clones" ${ }^{\text {"233 }}$ to "every clone is genetically

228 See Seidel, supra note 4 , at 23.

229 See id. at 24-27.

230 Such a ban would prohibit both reproductive and therapeutic cloning as both begin by enucleating a human egg and inserting the DNA from a donor cell.

See, e.g., Mo. ANN. STAT. $\$ 1.217$ (West 2002) (providing that "no state funds shall be used for research with respect to the cloning of a human person").

${ }^{232}$ See Four Rabbits Cloned From Adult Cells, WASH. Post, Mar. 30, 2002, at A4.

233 See Alan Colman, Comment $\mathcal{E}$ Analysis: Letters: Dolly, The Media Hog, ThE GUARDIAN, Apr. 24, 2002, at 17. 
and physically defective." ${ }^{234}$ Finding the reality amid these vastly diverging reports is a challenge, one complicated by the fact that the science continues to evolve daily.

The facts surrounding Dolly's birth are now well-known. Dolly was the only sheep to survive the 277 attempts at SCNT, ${ }^{235}$ which called into question the efficiency of cloning as a method of reproduction. ${ }^{236}$ In January 2002, it was reported that Dolly suffers from arthritis, a condition that is thought to be unusual for a sheep in her age group. ${ }^{237}$ Moreover, recent retrospective reports list defects occurring regularly in cloned animals, including gigantism (excessive size) in cloned sheep and cattle, placentas up to four times the normal size in mice, and heart defects in pigs. ${ }^{238}$ Researchers at the University of Cincinnati reported that cloned mice became obese after three weeks and grew to nearly three times larger than normal mice as they aged. ${ }^{239}$ Other experiments with cloned mice found damaged immune systems, spontaneous abortions, abnormal births, and premature deaths. ${ }^{240}$

Researchers who report these clinical findings on cloned animals are generally unsure why these defects occur. One theory

234 See Jonathan Leake, All Clones Defective, Says Dolly Creator, The Australian, Apr. 29,2002 , at 3 .

235 See Wilmut et al., supra note 1. Specifically, Dr. Wilmut and his colleagues reported the successful fusion between adult mammary gland nuclei and enucleated oocytes to the blastocyst stage in 29 out of 277 attempts (eleven percent), and only 1 of 29 (three percent) blastocysts transferred and developed into a live lamb. Id.

Recent reports suggest that the success rate in cloning animals is between one to five percent, meaning that up to ninety-nine percent of cloned animals do not survive birth. See Michele Grygotis, Researchers Find Cloned Mice Prone to Obesity in Adulthood, Have Shortened Lifespans, Genetic Engineering Research, 12 TRANSPLANT NEWS, Mar. 31, 2001. Other researchers report much higher overall survival rates. For example, animal researchers at the University of Georgia Athens report that $14.3 \%$ of cloned bovine embryos developed into healthy, normal animals. See Rebecca McCarthy, UGA Clones Calf From Dead Animal, ATLANTA J. \& Const., Apr. 26, 2002, at 1A. As a measure of perspective, these figures can be compared to estimates of the number of human embryos that develop into live offspring. Two researchers recently reported that "a conservative estimate is that at least two-thirds of the products of oocyte and sperm fusion are in some way defective" meaning that the embryos never implant or perish very early in development. Howard W. Jones \& Lucinda Veeck, What Is An Embryo?, 77 FERTILITY \& STERILITY 658 ( 2002).

237 See Milestones In Cloning Research, The Scotsman, Apr. 11, 2002, at 8; see also Leake, supra note 232, at 3.

${ }^{238}$ Leake, supra note 232.

239 See Michele Grygotis, Researchers Find Cloned Mice Prone to Obesity in Adulthood, Have Shortened Lifespans, Genetic Engineering Research, 12 TransPlant News, Mar. 31, 2001.

${ }^{240} I d$. 
holds that cloned animals have shortened telomeres, ${ }^{241}$ the bits of genetic material at the tips of chromosomes that wear down each time a cell divides. ${ }^{242}$ Shorter than normal telomeres essentially means that cells start out older and may die off sooner, possibly translating into a shorter lifespan for the cloned animal. ${ }^{243}$ Other researchers speculate that cloning problems are due to inadequate or inappropriate "reprogramming" of genes during the process of injecting DNA into an enucleated egg. ${ }^{244}$ Still others believe that the cloning process can turn any gene on or off at random with an unpredictable and potentially devastating impact on the health of the cloned animal. ${ }^{245}$

Reports of the dangers of animal cloning share the media stage with claims of success and progress in understanding and improving the science of cloning. The sheer number of successfully cloned species indicates the rapid progress of animal cloning research. To date, researchers have successfully cloned seven animal species, most recently cats and rabbits. ${ }^{246}$ In December 2001, California-based Genetic Savings \& Clone teamed with researchers at Texas A \& M University to clone a cat, appropriately named "cc" for "copycat." By all accounts, cc remains a normal, healthy cat. ${ }^{248}$ A few months after cc's birth, French researchers announced the birth of healthy rabbit clones. ${ }^{249}$ The rabbits had been born a year earlier, but

241 Id.

242 Id.

243 Id.

244 See Health Dangers of the Human Clones, DAILY MAIL, Apr. 29, 2002, at 33.

245 Id.

246 The seven species are sheep, rabbits, cattle, goats, mice, pigs, and cats. See Four Rabbits Cloned From Adult Cells,WAsh. Post, Mar. 30, 2002, at A4. In 2000 Oregon researchers produced a rhesus monkey named Tetra by splitting early stage embryos and then implanting the pieces into a host monkey. See Cloning Kerfuffle; The U.S. President and the Pope Are Among the Many Who Condemn the Use of Embryos for Human Cloning, LONDON Free Press, Nov. 27, 2001, at A6. The process of embryo splitting used to conceive Tetra is not the same as the process used in Dolly's birth; embryo splitting begins by creating an embryo using two genetic sources-one male and one female. The cells or blastomeres of the early embryo are then separated and the nucleus from each of these blastomeres is placed in an oocyte which then becomes an embryo. This process produces a finite number of identical offspring, each having the same genome as the original embryo. See Seidel, supra note 4, at 24-28. Dolly, in contrast, is the genetic twin of the single sheep whose cell was used for the somatic cell nuclear transfer. To date, researchers have been unable to produce a monkey using somatic cell nuclear transfer.

247 See Cloning: Commercial Cloning of Pets Two Years Away, Company Said, GenOMICS \& Genetics WkLY., Apr. 12, 2002, at 14.

${ }_{248}$ See Ben Carlson, Our Clones Are In Perfect Health, Sunday Telegraph, Apr. 21, 2002, at 20.

${ }^{249}$ See David Brown, A Big Hop Forward: Rabbits Cloned; Research Promise Seen In 
researchers delayed announcing the births until the rabbits started to reproduce normally. ${ }^{250}$ In announcing the cloning achievement, researchers assured the public that "the animals were mature and their good health certain."

In addition to claims of health for specific species, scientists have reported on the overall good health of cloned animals. In a study published in the prestigious journal Science, researchers compared cloned cows to cows conceived through artificial insemination and found no difference in their health status. ${ }^{252}$ In addition, a recent survey of all cloned live-born animals concluded that the majority remains healthy. Moreover, the survey found that the health of the natural offspring of cloned animals is no different from non-cloned animal offspring. ${ }^{253}$ Dolly herself became a mother in April 1998 when she gave birth to Bonnie, a lamb conceived "the old-fashioned way" with a mountain ram named David. ${ }^{254}$ In 1999, Dolly gave birth again, this time to triplets, and in 2000 she bore twins, with no complications reported for any of these offspring. ${ }^{255}$ Today, Dolly joins roughly 5,000 other animals conceived through SCNT in the past six years. $^{256}$

With the number of cloned animals poised to multiply in the months and years ahead, legitimate queries are raised about animal cloning and its effect on human cloning. Will success in the animal arena give implied authorization for researchers to apply their fund of knowledge to human reproduction? Or will scientists search for more reliable assurances of the safety and efficacy of cloning as applied to human beings? Though we have some knowledge about the degree to which experiments and procedures on animals translate to human outcomes, we will only know about the effects of SCNT when the first embryo, fetus, and child is created. For some, the leap from animal experiments to human conception is far too grave a prospect to contemplate; for others, it is a necessary and

\footnotetext{
Second Lab Animal to be Replicated, WASH. Post, Mar. 30, 2002, at A1.

${ }^{250} I d$.

251 Id.

252 See William Hathaway, Study Finds Cloned Cows Like Any Others, HARTFORD Courant, Nov. 24, 2001, at A5. Specifically, the researchers reported that they "did not observe genetic defects, immune deficiencies, gross obesity, or other drastic abnormalities cited by other researchers." Id.

${ }^{253}$ See Colman, supra note 231, at 17.

254 See Michael Seamark, A Natural-Born Beauty As Dolly Has A Little Lamb, DAILY MAIL, Apr. 24, 1998, at 17.

${ }^{255}$ See Jill Stevenson, The Six Years Which Transformed Medicine, The Scotsman, Jan. 5,2002 , at 3 .$$
{ }^{256} I d \text {. }
$$ 
inevitable step in the advancement and development of humankind.

To date, there have been few if any calls for banning reproductive cloning in animals. ${ }^{257}$ The merits and rationales for continuing to perfect the science of cloning in animals seem markedly different from those associated with human cloning. Reproductive cloning of the human species has been linked to narcissism and nefarious desires to engineer our children "to custom specifications." ${ }^{258}$ But when performed on animals, cloning is seen as beneficial to humans. ${ }^{259}$ The benefits of animal cloning include the production of superior cattle for meat consumption, ${ }^{260}$ the revivification of a lost pet for lifetime companionship, ${ }^{261}$ and the creation of animals for use in medical research. ${ }^{262}$ With these significant benefits to mankind, it seems unlikely that efforts to learn

257 There have, however, been calls for banning the use of cloned animal products, the impact of which would be to significantly reduce the interest in cloning animals. See Hathaway, supra note 250, at A5.

258 See Judith F. Daar, Editorial, We Can Tackle Cloning Responsibly, L.A. Times, June 2, 2002, at B19 (quoting a speech delivered by President Bush on the dangers of human cloning).

${ }^{259}$ An interesting question arises as to the benefit, if any, that befalls the animal who is cloned. Animals rights activists might very well argue that cloning is just as harmful to animals as it is to humans because of the safety and efficacy problems that have arisen, but such arguments do not seem to have stemmed the tide of increasing cloning experimentation on animals. Another interesting development in the animal world focuses on reviving extinct species using cloning. In May 2002 researchers announced plans to clone an extinct Tasmanian tiger. Declared extinct in 1936, the tiger's DNA has been successfully replicated using DNA from a preserved pup specimen. See Researchers Announce Plans to Clone Extinct Tasmanian Tiger, Channel News Asia, May 28, 2002. Query the human benefit to such an attempt. The animal was hardly a beloved species; it was hunted as vermin for attacking sheep, garnering a bounty for every carcass produced.

${ }^{260}$ See Rebecca McCarthy, UGA Clones Calf from Dead Animal, ATLANTA J. \& Const., Apr. 26, 2002, at 1A (reporting that scientists believe cloning technology will allow cattle farmers to stock herds with "cows capable of producing meat [with heritable traits] such as tenderness and marbling").

261 See Cloning: Commercial Cloning of Pets Two Years Away, Company Said, Genomics \& Genetics WkLY., Apr. 12, 2002, at 14 (reporting on the Missyplicity Project, a \$3.7 million effort to clone a mixed-breed pet dog named Missy).

${ }^{262}$ See David Brown, A Big Hop Forward: Rabbits Cloned; Research Promise Seen In Second Lab Animal to be Replicated, WASH. Post, Mar. 30, 2002, at A1. Reporter Brown explains the usefulness of rabbit cloning as follows:

Rabbits are used extensively in heart disease research. They also are used to make monoclonal antibodies, which are immune-system proteins used to diagnose and in some cases treat diseases. The rabbit immune system resembles that of human beings. That has made the species useful in studies of organ rejection after transplant. In addition, much of the basic research on reproduction that led to successful cloning was done on rabbits. 
more about cloning through animal studies will be halted.

Moreover, it seems equally unlikely that any ban on human reproductive cloning will affect research in the animal kingdom. In fact, the call for a human cloning ban may flow directly from the ongoing progress in animal cloning. Those opposed to human cloning because of safety and efficacy concerns may call for a temporary ban until full-fledged results from animal studies can be evaluated. Policy groups such as the National Bioethics Advisory Commission and the National Academy of Sciences, which urged for a temporary moratorium to be placed on reproductive cloning, seem open to supporting the technique if they were convinced that children born of the process would be as healthy as children born from ordinary conception. For these groups and others like them, animal cloning may be the gateway to human cloning. Banning human cloning now may have the effect of accelerating research on animal cloning so that a sufficient number of species can be successfully cloned, including species closest to humans, to assuage safety concerns. Thus, in the end, a ban on human cloning will not thwart efforts to clone multiple animal species and may ultimately enable the production of sufficient evidence to support moving forward with cloning human beings.

\section{Inroads In Human Cloning}

The race to legislate national and even international bans on human reproductive cloning can be evaluated in terms of its practical effect on researchers and others anxious to garner a place in history for being the first to clone a human being. Thus, the practical effects of banning human cloning should be considered either before or at the same time such bans are widely adopted. If bans will have no effect in stopping attempts to clone a human being, what ancillary effects will they have? If the net effect of such bans is negative or even neutral, can they be justified in light of the false sense of security they may invoke? Human nature is such that bans on conduct can serve to incite curiosity, often leading to irresponsible conduct. Should human cloning be the victim of such natural instincts, we must seriously question the value of an outright ban.

As noted above, a number of U.S. states as well as numerous countries have already banned human reproductive cloning. ${ }^{263}$ Yet efforts to clone a human being are ongoing in the United States and abroad. One of the earliest to announce cloning aspirations was Dr.

\footnotetext{
263 See supra notes $20 \& 33$.
} 
Severino Antinori, an Italian fertility specialist who promised in August 2001 that he would work to create the first cloned human being. ${ }^{264}$ In April 2002, Dr. Antinori surfaced again, this time amid rumors that he is responsible for the first ongoing pregnancy using a cloned embryo. ${ }^{265}$ The Gulf News, an English-language newspaper in the United Arab Emirates, reported that Dr. Antinori announced at a local conference that one woman in his fertility program was in the early stages of a cloned pregnancy. ${ }^{266}$ Later in the month, Dr. Antinori claimed that he was aware of, but not responsible for, three ongoing cloned pregnancies of babies in their ninth, seventh, and sixth weeks of gestation. ${ }^{267}$ Though the doctor claimed he was "not implicated in any way, ${ }^{268}$ he did reveal the country of origin of the three women as two former Soviet states and one Islamic country. ${ }^{269}$ He made this comment after remarking that China, India, Russia, and the Muslim countries are more favorable to the idea of human cloning than many other countries. ${ }^{270}$

On December 26, 2002, it appeared that Dr. Antinori was upstaged by a group known as Clonaid, which announced the birth of the world's first human clone. ${ }^{271}$ The baby, nicknamed Eve, was alleged to have been born outside the United States to American parents. ${ }^{272}$ Clonaid's president, Brigitte Boisselier, offered no proof that the birth had occurred, raising skepticism among the scientific community. ${ }^{273}$ Clonaid continues to announce the birth of cloned babies, ${ }^{274}$ but to date has produced no evidence that such a task has

${ }^{264}$ See Sheryl Gay Stolberg, Despite Opposition, Three Vow to Pursue Cloning of Humans, N.Y. Times, Aug. 7, 2001, at A1.

265 See First Human Cloning Pregnancy Reported: Scientists Skeptical, TrANSPLANT NewS, Apr. 12, 2002.

${ }^{266} I d$.

267 See Graham Diggines, Doctor Says Women Are Carrying Clones, EDINBurGH EvEning News, Apr. 24, 2002, at 2. Other scientists doubt the reports of multiple cloned pregnancies are true. See Human Clone Race to Deliver in 2003, MX, May 16, 2002, at 7 .

268 Diggines, supra note 265, at 2.

269 Id.

$270 \quad I d$.

271 Clonaid is a private company affiliated with the Raelian religious sect. Raelians believe that space travelers created the human race by cloning. Among other things, Raelians believe cloning is the path to eternal life, transferring memories and consciousness from one copy to the next. See Dana Canedy \& Kenneth Chang, Group Says Human Clone Was Born to an American, N.Y. Times, Dec. 28, 2002, at A16.

Id.

273 See Gina Kolata, Experts Are Suspicious of Group's Claim of Cloned Human's Birth, N.Y. Times, Dec. 28, 2002, at A16.

${ }^{274}$ David Carr, Networks Say Former Editor Tried to Sell Clone "Exclusive", N.Y. TIMES, Jan. 5, 2003, at 14 (detailing Clonaid's claims to have birthed two cloned babies). 
been accomplished. ${ }^{275}$ In an ironic twist, Dr. Antinori, the first doctor to make claims that he would accomplish human cloning, dismissed Clonaid's claims, saying the group "has no credibility in the science community." ${ }^{276}$ At the same time, Dr. Antinori maintains that a consortium of scientists with whom he is affiliated has created at least three pregnancies using cloning techniques. ${ }^{277}$ To date, no evidence of any human clone has been presented to the scientific community or to the public at large.

We may eventually learn whether the rumors and attributions surrounding Clonaid and Dr. Antinori are in fact true if a healthy baby is born and the child's genome is verified as an identical match to an existing person. Importantly, we may not learn the details surrounding the birth of a cloned child if the infant suffers from any serious health problems or dies in the neonatal period. Most probably, no matter what the outcome of these alleged initial pregnancies and births, inquiry into human cloning will continue. Clonaid and Dr. Antinori may be the only researchers now willing to air publicly their reproductive cloning efforts, but we can be sure that other attempts are underway.

While no one in the United States has yet to claim a purposeful advancement of the science of human reproductive cloning, researchers at Advanced Cell Technologies (ACT), a biotechnology company based in Worcester, Massachusetts, have announced success at cloning human embryos. ${ }^{278}$ According to ACT, the experiments were conducted not for reproductive purposes, but to create a source of stem cells for therapeutic purposes. ${ }^{279}$ In November 2001, ACT published a study in the peer-reviewed on-line journal E-biomed detailing experiments with enucleated eggs and insertion of DNA from a donor cell. ${ }^{280}$ In the end, none of the eggs survived beyond the blastocyst stage and the possible blastocysts that did develop lacked the inner cell mass that yields stem cells. ${ }^{281}$ Despite the apparent lack of success in producing a viable human embryo, ACT's actions were condemned for what they portended about the

275 Id.

276 Italian Authorities Investigating Fertility Doctor Pursuing Human Clones, GENOMICS \& GenetiCs WkLY., Feb. 14, 2003, at A15.

277 Id.

278 See Gina Kolata, Company Says It Produced Embryo Cells, N.Y. Times, Nov. 26, 2001, at A14.

279 See Gina Kolata with Andrew Pollack, A Breakthrough on Cloning? Perhaps, or Perhaps Not Yet, N.Y. Times, Nov. 27, 2001, at A1.

${ }^{280}$ See Gina Kolata \& Andrew Pollack, supra note 279, at A1.

281 Id. 
possibility of human cloning in the future. ${ }^{282}$ Nevertheless, ACT vowed to continue its efforts to perfect human therapeutic cloning "as a potentially limitless source of immune-compatible cells for tissue engineering and transplantation medicine."

In addition to the research efforts of American biotechnology companies such as ACT, studies are underway in other countries that certainly rival and perhaps surpass the work of U.S. scientists. Scientists at Xiangya Medical College in China claim to have cloned dozens of human embryos over the past two years for medical research purposes. ${ }^{284}$ These researchers are said to be one of two teams of scientists in China currently working on embryo cloning experiments. ${ }^{285}$ Initial accounts reveal that the Chinese scientists have been able to grow a cloned embryo to the blastocyst stage, extract stem cells from the inner cell mass of the blastocyst, and maintain the stem cells in the laboratory for three generations. ${ }^{286}$ If this is the case, these researchers have far exceeded the reported capabilities of U.S. researchers. Although the Chinese researchers emphasize that their work is aimed at therapeutic cloning, there is no scientific reason why the techniques being perfected could not also be used in reproductive cloning. In a recent interview, Dr. Lu Guangxiu, the professor who heads the Xiangya team, was asked about the possibility of human reproductive cloning. "It is," she remarked, "an irresistible trend." ${ }^{287}$

This "irresistible trend" intrigues researchers not only because of its scientific newness, but also because of its potential for garnering enormous research dollars. On the heels of Dr. Lu's success, the Chinese government increased her annual research grant. ${ }^{288}$ In addition, she was able to convince one of China's largest companies, China International Trust \& Investment Corporation, to invest three million dollars in the fertility clinic she runs. ${ }^{289}$ Clearly, the opportunity for profit has propelled many countries into the cloning race. Nations in Europe and Asia are creating regulatory

${ }^{282}$ See Cloning Kerfuffle; The U.S. President and the Pope Are Among the Many Who Condemn the Use of Embryos for Human Cloning, LONDON FreE PrEss, Nov. 27, 2001, at A6.

${ }^{283} I d$.

284 See Karby Leggett \& Antonio Regalado, As West Mulls Ethics, China Forges Ahead in Stem-Cell Research, WALL ST. J., Mar. 6, 2002, at A1.

285 Id.

${ }^{286} I d$.

287 Id.

288 Id

${ }^{289} I d$. 
environments friendly to therapeutic cloning to attract both researchers and research funding. ${ }^{290}$ For example, lawmakers in Britain and Singapore recently revised their laws to allow stem cell research using human embryos. ${ }^{291}$ While the impetus for such reforms is clearly profit-oriented, the byproduct of such development will undoubtedly advance the science of human cloning. Once scientists are adept at creating blastocysts using SCNT, the step toward implanting a cloned embryo into a woman's uterus is a comparatively small measure.

The recent and prospective future attention on manipulation of the human embryo for medical and research purposes has created a race for greater understanding of the science of cloning. It is clear that researchers in the United States and abroad will continue their marathon efforts to clone human embryos, perhaps now for therapeutic purposes, but with a keen awareness of the reproductive possibilities lurking in the background. A ban in any particular U.S. state will merely move operations across state lines; a ban in any particular country will likewise make other nations more friendly to the cloning community. As described earlier, cloning is a "genie out of the bottle" phenomenon. Ongoing experimentation both here and abroad is a predictable and natural response to an emerging technology that beckons mankind to unravel the mystery of human life.

\section{The Effects of Banning Conduct}

The inevitability of human reproductive cloning may be in the minds of many scientists, but it is still perceived as a stoppable evil to many lawmakers. Thus, the march toward a total ban on reproductive cloning continues, buoyed by the public's revulsion to the very idea of cloning ${ }^{292}$ and the thoughtful comments of several prestigious panels that have recommended outlawing the practice. ${ }^{293}$ If human reproductive cloning is banned in the United States, as it has been in most of Europe, we must ascertain what effect those laws will have on the practice of cloning. A ban in the United States and Europe, or even a ban with more international scope, as has been

290 See Britain at Cutting-Edge of the Biotech Boom, THE Business, Apr. 7, 2002, at 13 (reporting on a vote by parliament in February 2002 to end the ban on stem cell research with human embryos, including cloning); see also Chan Kay Min, Call for Body to Check Stem Cell Studies, The STRAits Times, Jan. 8, 2002, at 3 (describing Singapore's Bioethics Advisory Committee's proposal to regulate stem cell research). 291 Id.

292 See supra notes 35-36 and accompanying text.

293 See supra notes 43-47 and accompanying text. 
contemplated, seems unlikely to actually stop the science from being developed and the technique employed.

The unprecedented step of banning a prospective scientific technique will not prevent the technology from being developed, but rather will negatively impact the way in which the development occurs. Human nature is such that legislative bans do not always stop prohibited conduct; in fact, in some cases a ban may create an incentive for action. Certainly our criminal justice system is replete with demonstrations of this principle. Banning or criminalizing conduct has not made criminal acts extinct, and no doubt many a prisoner has earned that status by purposefully defying known prohibitions in the name of self-aggrandizement. While the comparison between criminal acts and scientific inquiry may be a weak one, it nonetheless highlights the reality that when those in power declare certain conduct to be off limits for its citizenry, rarely if ever will such conduct cease in that society. Even threats and demonstrations of severe penalties do not prevent displays of unwanted conduct. ${ }^{294}$

In the cloning context, if Congress enacts a total ban, we should expect that ongoing efforts will move underground in the United States and offshore to more cloning-friendly nations. Today, we are aware of a very small pool of researchers working openly in the area of embryo cloning, and all publicly state that their aims are strictly therapeutic. ${ }^{295}$ But we are also aware of hints at secret research being conducted on reproductive cloning. ${ }^{296}$ Those hints are coming from places outside the United States, but we are not immune from clandestine efforts at human cloning within our borders. Last summer at a symposium sponsored by the National Academy of Sciences, Dr. Brigitte Boisselier, a chemist with Clonaid, announced that she had made progress toward human cloning. ${ }^{297}$ Though Dr.

294 If they did, one might argue, states that impose the death penalty would be free of murder and other capital crimes. Of course, the deterrent effect of capital punishment is highly controversial and well beyond the scope of this article.

${ }^{295}$ See supra notes 265-69 and accompanying text.

296 See supra notes 259-63 and accompanying text.

297 See Researchers Vow Human Will Be Cloned; 3 Maverick Scientists Buck Colleagues' Advice, Houston Chronicle, Aug. 8, 2001, at A1. Dr. Boisselier claimed to have developed a test to determine whether cloned embryos are genetically normal so that they will result in the birth of normal children. Other scientists who attended the symposium dismissed these claims as "ludicrous." Id. In December 2002, Dr. Boisselier announced that Clonaid had succeeded in cloning the world's first human child, a girl nicknamed Eve. To date, Clonaid claims to have cloned at least three babies, but no proof of these efforts has been produced. See Amid Growing Scrutiny, Clonaid Says Third Cloned Baby Has Been Born, Genomics \& Genetics WkLY., Feb. 14, 2003 , at 15 . 
Boisselier did not discuss the location of her research efforts, later reports revealed that she had been operating in a laboratory in Nitro, West Virginia. ${ }^{298}$ The "laboratory," as it turns out, was a single classroom in the Nitro Community Center, a facility that also houses a day care center and the Nitro Police Department. ${ }^{299}$ The laboratory was shut down after agents of the Food and Drug Administration began to investigate rumors of a cloning facility in Nitro. ${ }^{300}$

What was perhaps most unsettling about Dr. Boisselier's efforts was that they were supported by Mark Hunt, a lawyer and member of the state House of Delegates, who had paid the research group nearly $\$ 500,000$ to clone his 10 -month old son who died after surgery for a heart defect. ${ }^{301}$ Mr. Hunt's grief over the loss of his son made him vulnerable to the promises of a single researcher, a researcher who lacked the background and support to fulfill even the most modest hopes of her sponsor. ${ }^{302}$ In the end, Mr. Hunt severed his ties with the cloning group because it was not making progress in the quest to create an identical twin of his lost son. ${ }^{303}$ Mr. Hunt is not alone in his private desire for the science of human cloning to come of age, nor is he likely to be the only victim of unscrupulous "researchers" who will continue to operate so long as they have a monopoly on those individuals and groups who wish to provide financial support to advance the cloning cause. Such "researchers" will thrive until they are replaced by skilled professionals whose training and experience truly holds the promise of safe and ethical progress in this difficult area.

Another byproduct of a ban on scientific research would be a "brain drain," as talented and well-funded scientists leave the United States to establish research centers in nations with hospitable working environments. We have already begun to see this brain drain to a small extent in the past year. ${ }^{304}$ In 2001, University of California researcher Roger Pedersen left his position at UC San Francisco to accept a post at Cambridge University in Britain. ${ }^{305}$ At the time of Dr. Pedersen's move, Congress was debating the merits of banning all

${ }^{298}$ See James A. Haught \& Tara Tuckwiller, Cloning Effort Hidden in West Virginia Town; Father Wanted to Duplicate Dead Son, WASH. Times, Aug. 14, 2001, at A1.

${ }^{299}$ Id.

${ }^{300} I d$.

${ }^{301} I d$.

${ }^{302} I d$.

${ }^{303}$ Id. Mr. Hunt is quoted as saying he ceased his financial support for Clonaid because "they weren't doing anything. They weren't working." Id.

304 See UC Researcher Admits Human Cloning, L.A. TIMEs, May 25, 2002, at A18.

${ }^{305} I d$. 
forms of cloning research, including both reproductive and therapeutic techniques. ${ }^{306}$ At the same time, Britain was considering ways to create opportunities for researchers to flourish in the field of therapeutic cloning, seen as a biotechnology boon for all its promise of new and innovative therapies. ${ }^{307}$ When Dr. Pedersen made the move from the United States to Britain, it was widely reported that the impetus for his relocation was the differing state of the law in the two nations. ${ }^{308}$ Now, as Britain joins several other European and Asian countries vying for the hefty biotech dollars thought to be connected to therapeutic cloning and stem cell research, it is likely that the brain drain will only accelerate if Congress succeeds in banning all forms of cloning. ${ }^{309}$

Banning conduct creates underground activities and banning cloning undoubtedly will have this expected result. The few details we have learned about Dr. Boisselier's activities should be all the warning we need. Her cloning experiments, whether actual or threatened, would have taken place in a totally unsupervised, unregulated environment. With underground cloning efforts, there will be no reporting to oversight organizations that could assess the safety, progress, or value of the experiments. There will be no peer review of any findings that emerge from the research. There will be no method to assure separation between the funding source for the research and the results of the research. The opportunity for conflict of interest among these unchecked researchers is tremendous, and the probability that they will report false, perhaps even intentionally falsified data, is high.

From a practical perspective, a ban on human cloning will only encourage development of irresponsible and ill-conceived research agendas. A ban may provide an initial period of solace and comfort, but the curiosity surrounding cloning is too great to repress the exuberance that will accompany any perceived progress in the field, whether lawfully or unlawfully begotten. The United States and a

306 Id.

307 Id.

308 Id.

309 I would also argue that the brain drain will be nearly as severe even if Congress bans only human reproductive cloning. A ban on reproductive cloning may mean that researchers will be scrutinized in their laboratories for any experiments they conduct. Since reproductive and therapeutic cloning begin with the same process, law enforcement officials will want to make sure that cloned embryos are not placed in a woman's uterus, or perhaps even frozen for later use. This type of oppressive environment may have a similar effect to an outright ban, i.e. making research in the United States unattractive for all the administrative complexities that will attach to cloning experimentation. 
number of other nations have long-standing research structures in place that could accommodate a steady and responsible path toward human reproductive cloning. Working together in an open environment, the best and the brightest scientists of our age could advance our understanding of human development, an advance that will once again remind us how much more is yet to be discovered.

\section{COnClusion}

The prospect of human cloning poses the unanswerable query: will it improve nature or doom the species? While the realities of a cloning-laden future are unknowable, we seem to have prejudged that future to be grim, besot with human misery by those who are the products of cloning and human indifference for those who reproduce in that fashion. Today's efforts to ban human cloning are emblematic of our own self-doubt, our fear that unraveling the mysteries of human life can only lead to our undoing. Humanity has always displayed this schizophrenic view of itself, on the one hand pressing to know more about the world around us, while displaying initial fear and hostility toward the very things we seek to discover. Cloning is merely the latest discovery to evoke these instinctive and legitimate reactions.

It is inevitable that advances in human cloning will far outpace our ability to halt the practice in any meaningful sense. Statutory bans, such as those in place in the United States, are of questionable moral and legal status, but perhaps most importantly they are of little practical effect. Rapid advances in animal cloning, coupled with renegade efforts to inaugurate the human cloning process, assure the viability of cloning as a future method of human reproduction. Reasoned regulation, not breakable barriers, seems a far better way to meet the challenges of a cloning future. Human cloning will only doom our species if we fail to recognize the power it has to improve the human condition. Harnessing that power is our challenge today because what we build will shape our future tomorrow and always. 